\title{
Experimental Study and Numerical Study on Shear Bearing Capacity of Shear Key Joints of Reinforced Concrete Open-Web Sandwich Plates
}

\author{
Hongna Lu, ${ }^{1}$ Huagang Zhang $\mathbb{D}^{1},{ }^{1}$ Kejian Ma, ${ }^{1}$ Qin $W u,{ }^{2}$ and Lan Jiang ${ }^{3}$ \\ ${ }^{1}$ Space Structures Research Center, Guizhou University, Guiyang 550025, China \\ ${ }^{2}$ College of Architectural Engineering, Guizhou Minzu University, Guiyang 550025, China \\ ${ }^{3}$ School of Electric and New Energy, Three Gorges University, Yichang 443000, China
}

Correspondence should be addressed to Huagang Zhang; hgzhang@gzu.edu.cn

Received 30 July 2021; Accepted 26 October 2021; Published 12 November 2021

Academic Editor: Rotana Hay

Copyright (c) 2021 Hongna Lu et al. This is an open access article distributed under the Creative Commons Attribution License, which permits unrestricted use, distribution, and reproduction in any medium, provided the original work is properly cited.

The shear key in the reinforced concrete open-web sandwich plate (RCOSP) is a block joint that connects with the top chord and the bottom chord. In order to understand the failure mode of the shear key and verify the accuracy of the current algorithm, a total of 9 test pieces are prepared and classified 3 groups were assigned longitudinal reinforcement (LR) ratios of $0.49 \%, 0.82 \%$, and $1.24 \%$, respectively. The horizontal concentrated static loading under simple support condition is carried out. The test results show that the shear key is horizontally cut and the concrete is pulled apart or crushed along the direction of chord width at the shear keychords area; the strain level of the concrete and stirrup of the shear key is lower averagely; the development of the horizontal displacement and the strain of the longitudinal bars of the test pieces goes through elastic, elastoplastic, and plastic stages; the ultimate load of the test pieces has almost no relationship with the reinforcement ratio of shear key but is controlled by the degree of crack development in the area where shear key connects with the chords. To avoid the current algorithm overestimating the shear capacity of shear key, the restricted condition of shear section is proposed. The finite element analysis (FEA) further verifies that the restricted condition of shear section proposed in this paper is reasonable and necessary.

\section{Introduction}

The open-web sandwich plate floor is a kind of novel floor developed on the basis of open-web grid, its appearance is similar to that of the reinforced concrete open-web grid in Figure 1(a), and the height of the open-web grid is $1 / 16$ to $1 /$ 18 in short span direction [1]. The open-web part is composed of top chord, bottom chord, and the shear key that connects with top and bottom chords; the surface course is cast-in-situ or precast reinforced concrete slab; see Figure 1(b) for its composition. This floor overcomes the disadvantage that the shear stiffness of the open-web grid is bad and has the following advantages:

(1) It is mostly used in large-span (commonly used span is 18 to $30 \mathrm{~m}$ ) multistory building and the floor height is small (1/24 to $1 / 30$ in short span direction), improving the land utilization
(2) The space between top chord and bottom chord can be used as channel for various kinds of pipelines; no suspended ceiling is required, playing a part in beautifying appearance and saving story height

(3) The existence of the gap between top chord and bottom chord can effectively reduce the dead weight of the structure and minimize the seismic effect

(4) The partition on the floor can be divided flexibly as needed

The study shows that, under the action of vertical load, the bending deflection with the top chord and bottom chord of the RCOSP is obvious, but the shear key mainly shows the shear deformation [2], the deformation of the open-web sandwich plate mainly is bending, which accounts for about $85 \%$ of total deformation, and the shear deformation accounts for about $15 \%$ [3] of total deformation. The flexural 


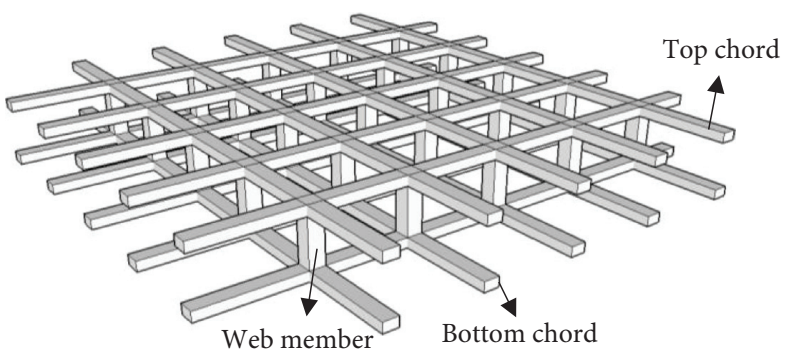

(a)

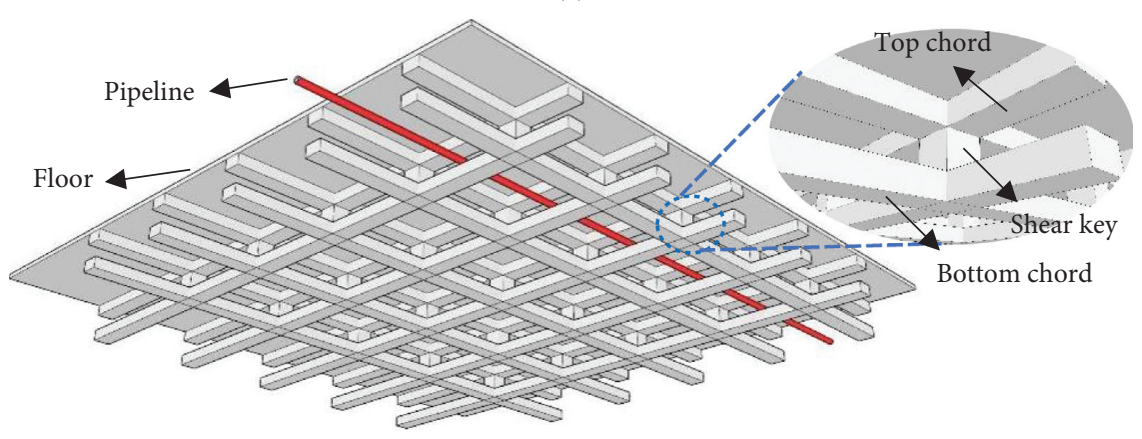

(b)

FIgURE 1: Structure composition schematic diagram. (a) Reinforced concrete open-web grid. (b) Reinforced concrete open-web sandwich plate floor.

behavior [4] and seismic behavior of the steel open-web sandwich plate are discussed by numerical analysis methods [5].

As the shear key is connecting the top and bottom chords of the open-web sandwich plate, it directly affects the integral mechanical properties of the open-web sandwich plate; understanding the mechanical properties and failure mode of the shear key in various kinds of open-web sandwich plates becomes the focus of the study at present. The experimental study on reciprocating loading of shear key joints of steel open-web sandwich plates (SOSP) with/ without stiffening chord provided is carried out, the results show that two types of joints have better seismic behavior and can meet the project design requirements, and the photo of the structure is shown in Figure 2(a) [6]. The experimental study on the shear key of SOSP shows that the joint has better shear bearing capacity and ductility $[9,10]$. A static loading test on shear key joints of SOSP is performed and the formula of the intersection beam analogy method is obtained [11]. The shear connectors also appear in the composite beam and beam column joints. By experimental study an empirical equation to predict the load capacity of the $\mathrm{V}$-shaped shear connector is obtained [12]. The shear strength, shear stiffness, failure mode, and relative slip characteristics of perforated panel connection joint in corrugated steel web composite beam are studied by means of tests [13]; the mechanical property of stud connectors in a fire and its influence on connection performance of the composite beam are studied [14]. Combined with experiments and finite element analysis, the failure mode and shear bearing capacity computational formula of high strength bolt connected in composite beam are obtained $[7,15]$, and the photo of the structure in [14] is shown in Figure 2(b). The test results show that the stud or bolt connection in light steel composite beam can ensure better shear bonding strength [16]; the H-shaped steel composite wooden beam can adopt inclined bolt steel-wood composite joint for shear connection [17]. The shear connection performance of woodconcrete composite beam is studied by using experimental method $[8,18]$, and the photo of the structure in [18] is shown in Figure 2(c). The experimental study on external stiffening chord joint between square hollow section column and $\mathrm{H}$-shaped steel beam and steel-concrete column-steel beam composite joint is carried out, and the computational method of shear strength is proposed $[19,20]$. The study shows that if the web in the beam column joint area is reinforced by using asymmetric chamfer, the shear bearing capacity of the joint area can be improved [21]. The gene expression program can be used to predict the computational model of shear bearing capacity of reinforced concrete beam column joint [22]. The studies in [23, 24] give the computational model and computational formula that are suitable for shear strength of reinforced concrete beam column joint under the action of earthquake.

The above studies mainly focus on different types of shear key joints in the steel open-web sandwich plate and other types of shear connection, while the experimental study of shear key joint in RCOSP has not been performed. The current algorithm considers that the stress of shear key joint is similar to that of the reinforced concrete corbel; the shear bearing capacity is mainly controlled by the single side LR of shear key joint [1]. To verify the accuracy of the current algorithm for shear bearing capacity of the shear key of RCOSP and understand the failure mode of shear key of the 

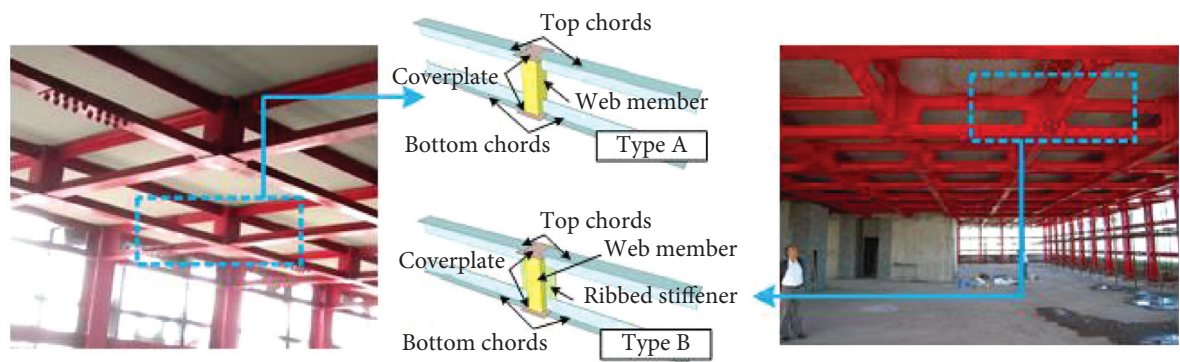

(a)

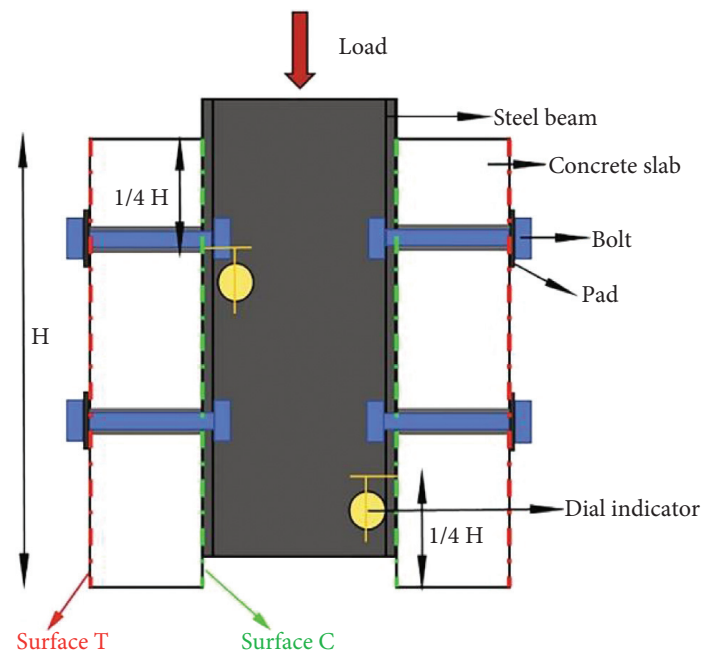

(b)

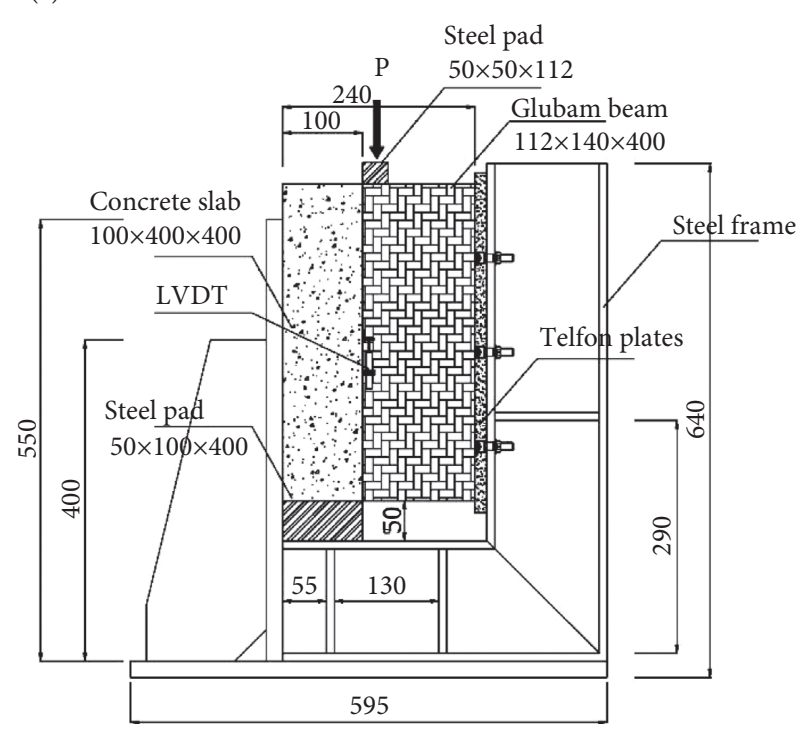

(c)

Figure 2: The structures in reference. (a) The steel structure in [6]. (b) The steel-concrete composite structure in [7]. (c) The wood-concrete composite structure in [8].

RCOSP, a total of 9 test pieces in 3 groups with different LR ratios of shear key are designed. The centralized static loading is carried out to obtain the crack development and failure mode of test pieces, understand the relationship of shear bearing capacity with LR ratios of shear key joint, and obtain the load-displacement curves of test pieces.

\section{Experiment Review}

2.1. Design of the Components. The experiment in this paper is completed in Key Laboratory of Structural Engineering of Guizhou Province, China. The mechanical simplified model of test pieces is shown in Figure 3; the sizes of test pieces are indicated in Figure 4(a). Three groups of test pieces with LR ratios of shear key of $0.49 \%, 0.82 \%$, and $1.24 \%$, respectively, are designed, three test pieces are prepared for each group, and the reinforcement arrangement of each group of test pieces is given in Table 1. The test pieces are prepared in horizontal position, as it is shown in Figure 5.

2.2. Mechanical Properties of Materials. Three groups of specimens were poured with ready-mixed concrete. Test results of the concrete cube compressive strength of each specimen group are shown in Table 2. The tensile strength and elastic modulus were calculated from the compressive strength [25]. Mechanical performance parameters of steel bar are shown in Table 3.

2.3. Loading Device and System. For the simple support of shear key joint, the single point horizontal centralized loading is adopted, a 100T Jack is selected for loading, and a $50 \mathrm{~T}$ load transducer is used to control the load values; the design of test loading device is shown in Figure 6, and the physical diagram of the loading device is shown in Figure 7. The loading rate is approximately $7 \mathrm{kN} / \mathrm{min}$, a load of $15 \mathrm{kN}$ is applied to each test piece at the first stage, a load of $30 \mathrm{kN}$ is applied at each stage from the second stage, each stage of load is stabilized for a time duration of $10 \mathrm{~min}$, and the crack development condition during the load stabilizing is observed and a corresponding note is made.

2.4. Arrangement of Measuring Points. To measure the horizontal displacement of the test pieces, a displacement meter shown in Figure 8 is arranged. The reinforcement strain gauges are arranged on the chord LR, shear key LR, and shear key stirrup, 32 reinforcement strain gauges are arranged on each test piece, and the positions and numbers of the arrangement are shown in Figure 9. The concrete strain gauges are arranged on the shear key and chord 


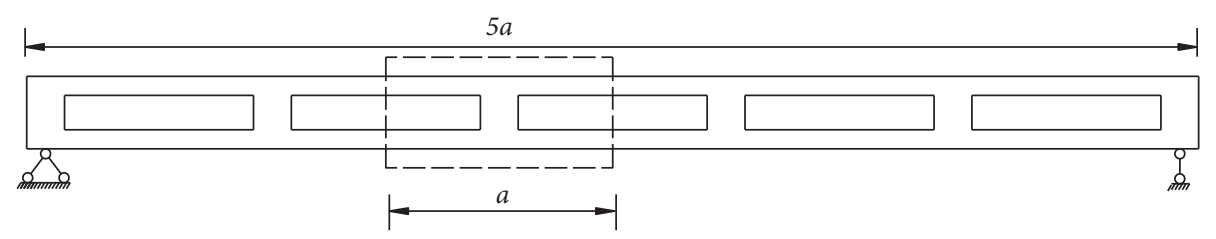

(a)
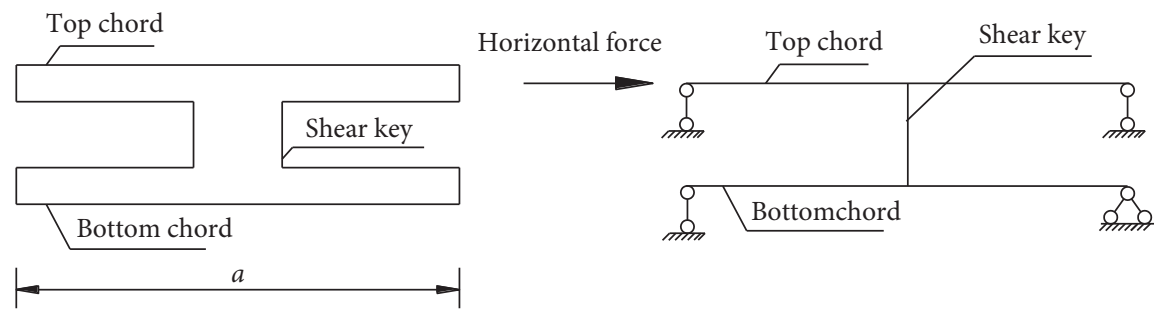

(b)

Figure 3: Mechanical model of test. (a) Object of the study. (b) Force diagram.

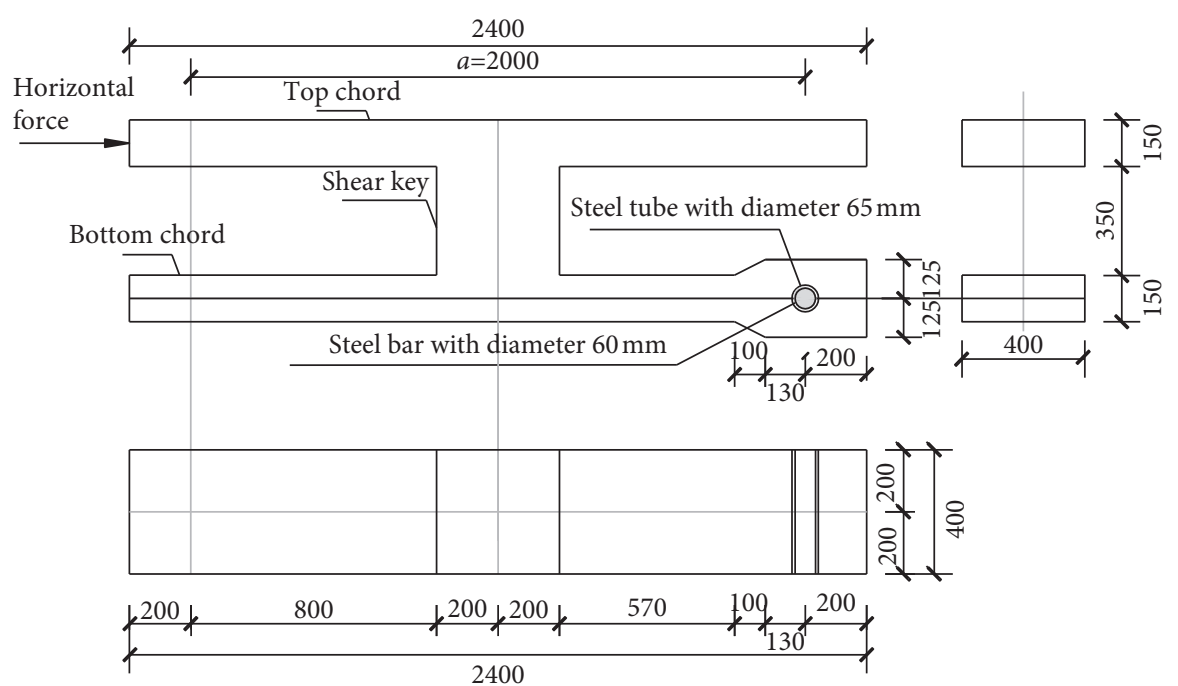

(a)

Embedded $10 \times 150 \times 400$ steel plate
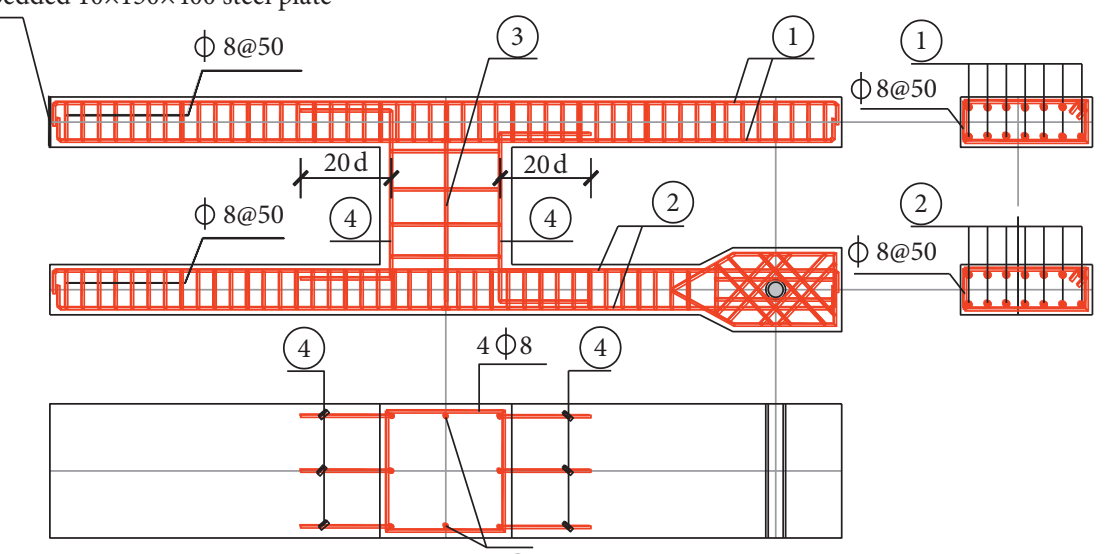

(3)

(b)

FIgURE 4: (a) Size diagram and (b) reinforcement arrangement diagram of test pieces. 
TABLE 1: Test piece reinforcement arrangement.

\begin{tabular}{|c|c|c|c|c|c|c|}
\hline \multirow[t]{2}{*}{ Group number } & \multirow[t]{2}{*}{ Specimen number } & \multirow{2}{*}{$\begin{array}{l}\text { Longitudinal steel bar of top chord } \\
\text { (1) }\end{array}$} & \multirow{2}{*}{$\begin{array}{l}\text { Longitudinal steel bar of bottom chord } \\
\text { (2) }\end{array}$} & \multicolumn{3}{|c|}{$\begin{array}{l}\text { Longitudinal steel bar } \\
\text { of shear key }\end{array}$} \\
\hline & & & & (3) & (4) & LR ratio $/ \%$ \\
\hline First g & $1-\mathrm{A} \sim 1-\mathrm{C}$ & $14 \varphi 12$ & $14 \varphi 14$ & $2 \varphi 8$ & $3 \varphi 12$ & 0.49 \\
\hline Second group & $2-\mathrm{A} \sim 2-\mathrm{C}$ & $14 \varphi 12$ & $14 \varphi 14$ & $2 \varphi 8$ & $3 \varphi 16$ & 0.82 \\
\hline Third group & $3-\mathrm{A} \sim 3-\mathrm{C}$ & $14 \varphi 12$ & $14 \varphi 14$ & $2 \varphi 8$ & $3 \varphi 20$ & 1.24 \\
\hline
\end{tabular}

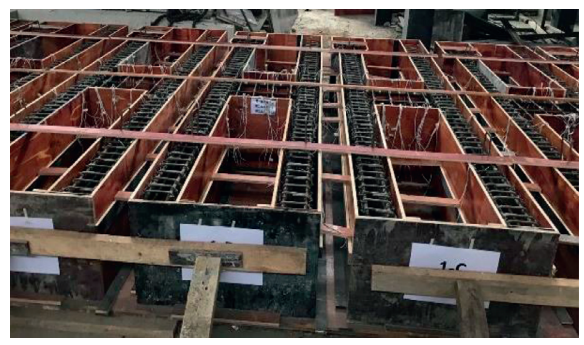

(a)

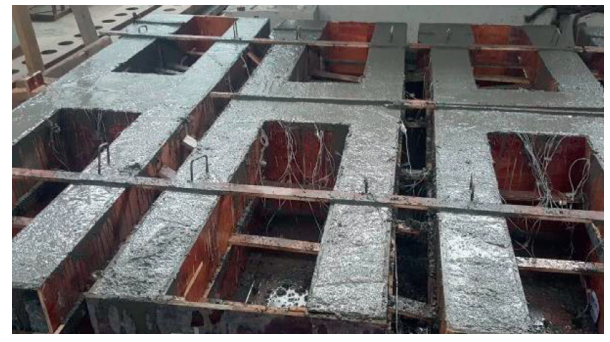

(b)

Figure 5: Making specimens. (a) Making models. (b) Pouring concrete.

TABLE 2: Mechanical properties of concrete.

\begin{tabular}{lcc}
\hline Measured compressive strength $f_{\text {cu, } \mathrm{k}}(\mathrm{MPa})$ & Tensile strength $f_{\text {tk }}(\mathrm{MPa})$ & Modulus of elasticity $E c\left(\mathrm{~N} . \mathrm{mm}^{-2}\right)$ \\
\hline 28.48 & 2.03 & $2.93 \times 10^{4}$ \\
\hline
\end{tabular}

TABle 3: Mechanical properties of the steel bar.

\begin{tabular}{lccc}
\hline$d(\mathrm{~mm})$ & $f_{y k}(\mathrm{MPa})$ & $f_{u k}(\mathrm{MPa})$ & $E_{s}(\mathrm{MPa})$ \\
\hline 8 & 447 & 558 & $2.14 \times 10^{5}$ \\
12 & 484 & 624 & $2.09 \times 10^{5}$ \\
14 & 412 & 591 & $2.01 \times 10^{5}$ \\
16 & 450 & 587 & $2.03 \times 10^{5}$ \\
20 & 481 & 599 & $2.06 \times 10^{5}$ \\
\hline
\end{tabular}

surface, the positions and numbers of the arrangement are shown in Figure 10, and 26 concrete strain gauges are arranged on an individual test piece. In the experiment, the synchronous collection of data from displacement meter, load transducer, and strain measuring are enabled by the test system.

\section{Experimental Phenomena and Failure Characteristics}

3.1. Description of Experimental Phenomena. The experimental phenomena and the failure load values of 3 groups of test pieces are roughly the same; the crack development process and law are described by taking test piece 3-A as an example. It is stipulated in the following description that the shear key is taken as the center, the left side refers to the end that is close to the horizontal loading, and the right side refers to the end that is close to the fixed hinged bearing. As the occurrence of cracks on the front and back of the shear key-chord connected area is almost similar, only the cracks on the front of the shear key-chord connected area are described:
(1) When loading to about $25 \%$ of the failure load, the horizontal cracks along the direction of chord width on the upper surface of the left-hand top chord occur; the cracks do not run through.

(2) When loading to about $35 \%$ of the failure load, the inclined cracks at the corner occur where the upper surface of the left-hand bottom chord connects with the shear key; two horizontal cracks along the direction of chord width occur on the upper surface of left-hand top chord; the cracks do not run through.

(3) When loading to about $45 \%$ of the failure load, the inclined cracks at the corner occur where the lower surface of the right-hand top chord connects with the shear key; two horizontal cracks that run through and extend to the side of the chord occur at the location that is close to the shear key on the lower surface of right-hand bottom chord.

(4) When loading to about $55 \%$ of the failure load, the horizontal cracks are developed along the direction of shear key cross section based on the diagonal cracks already that existed at the corner; the cracks do not run through.

(5) When loading to about $75 \%$ of the failure load, the horizontal cracks in the area where the shear key connects with chords further develop, which basically run through the shear key; the diagonal cracks extending to the chords occur at the location where the horizontal cracks of the shear key exist; the area where the shear key connects with chords is pulled apart or crushed along the direction of chords width; 


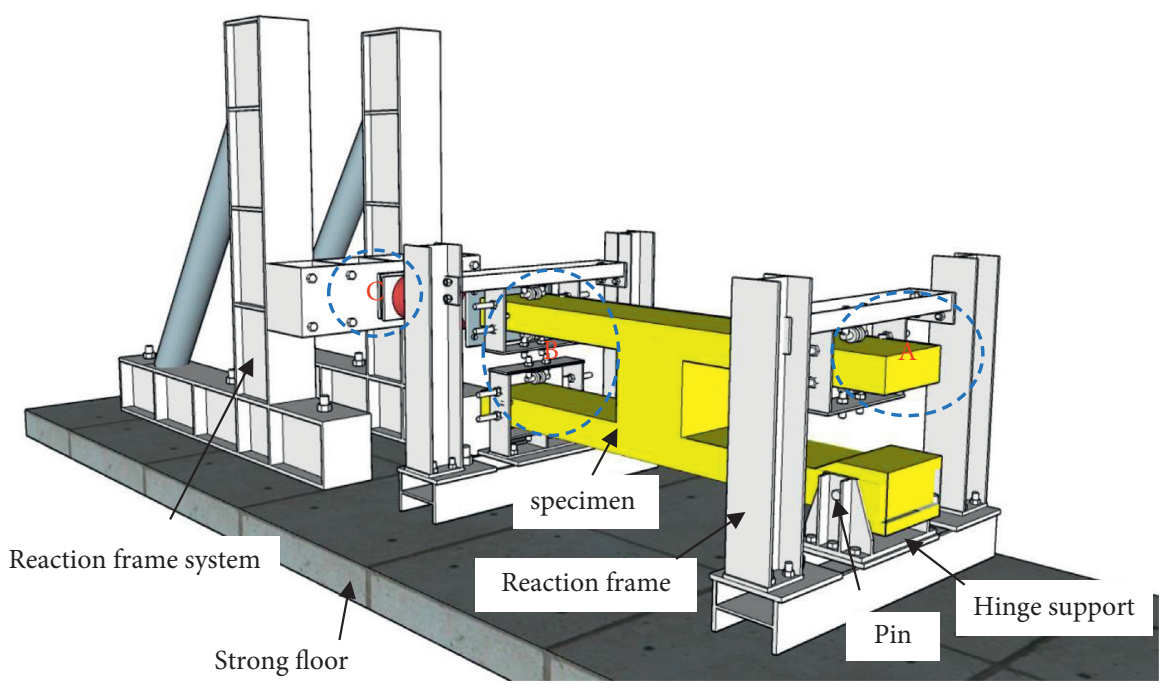

(a)

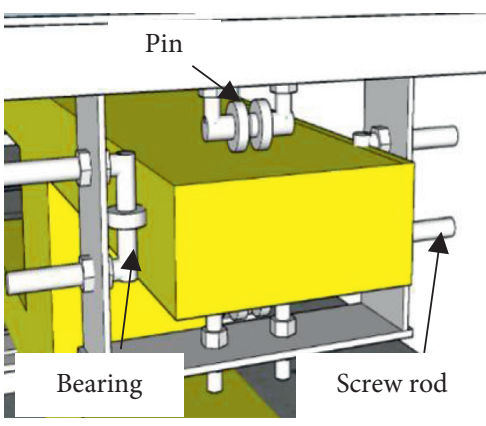

(b)

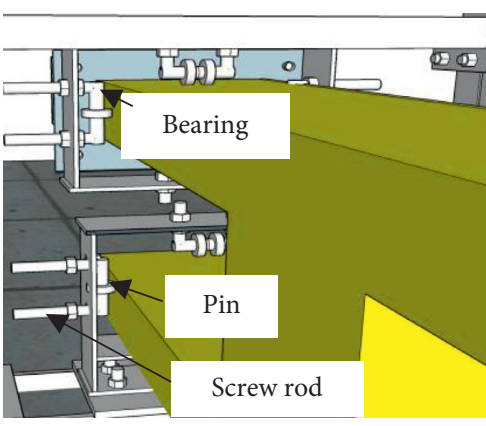

(c)

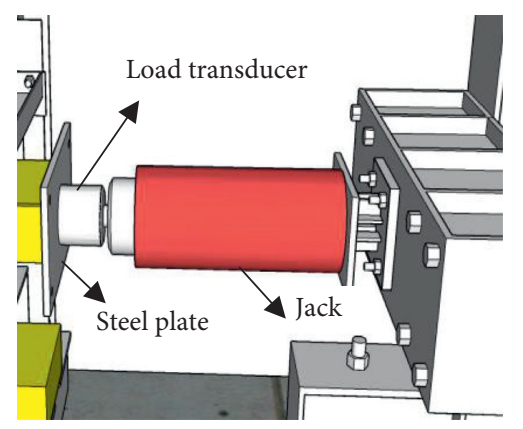

(d)

FIgURE 6: Design of loading device diagram. (a) Overall diagram of the designed test loading device. (b) Detailed diagram of area A. (c) Detailed diagram of area B. (d) Detailed diagram of area C.

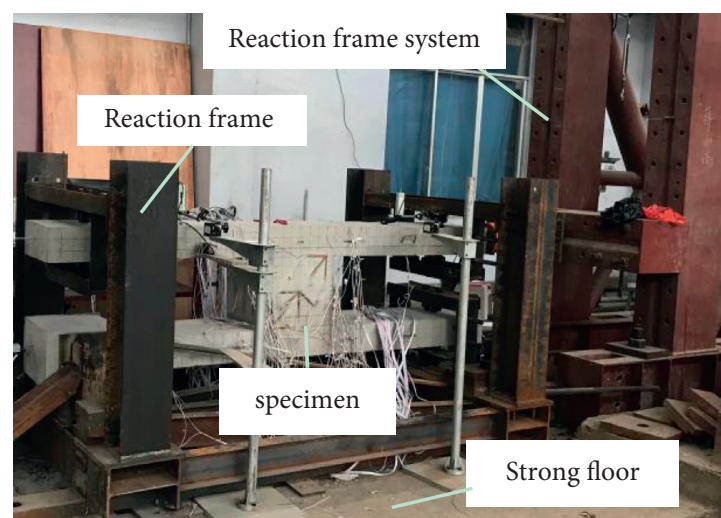

(a)

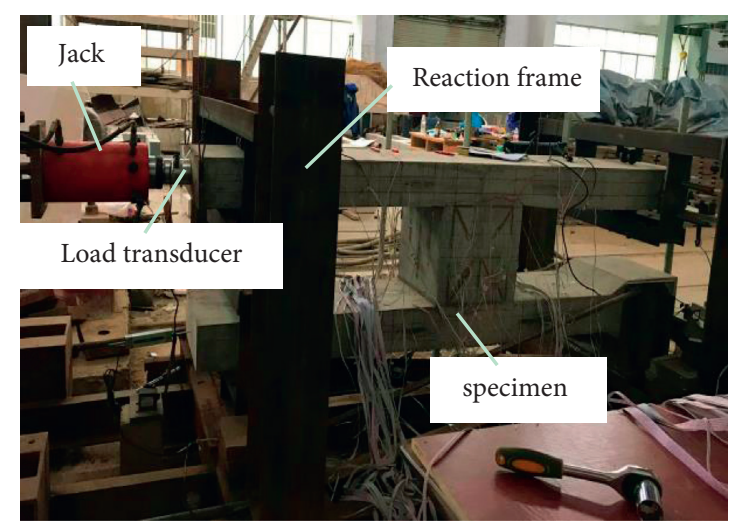

(b)

Figure 7: Test loading device diagram. (a) Back side of the test loading device. (b) Front side of the test loading device.

the existing cracks on the upper surface of the righthand top chord further develop and run through the chord width, and new cracks also occurred at the same time; the lower surface of right-hand bottom chord has 3 cracks that run through the chord width and extend to the side of the chord.
(6) When loading to about $95 \%$ of the failure load, no new crack occurs basically; the existing cracks further develop; when there is a continuous loading up to $306 \mathrm{kN}$, it is impossible for the loading to increase any more; the test piece is announced to be failure. In Figure 11, the contour lines of specimen are shown. 


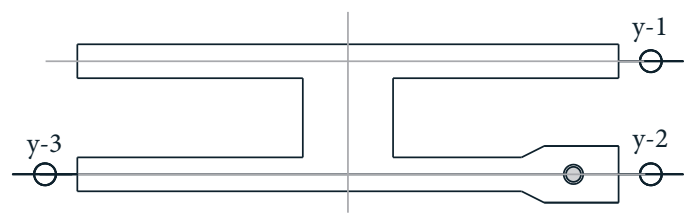

Figure 8: Layout of displacement meters.

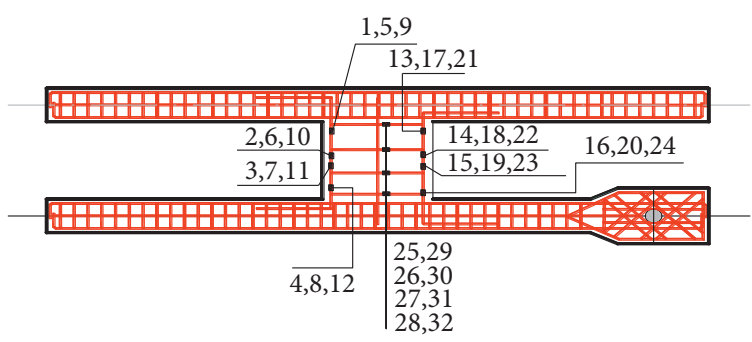

FIgURE 9: Layout of steel strain gauges.

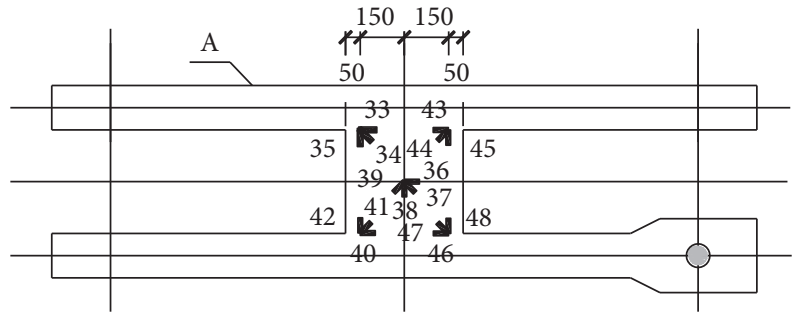

(a)

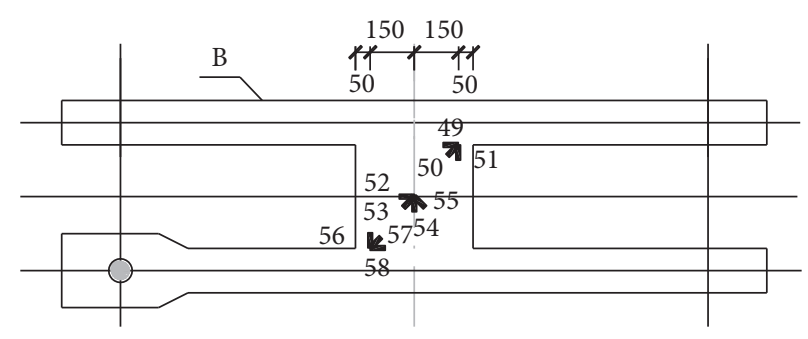

(b)

Figure 10: Layout of concrete strain gauges.

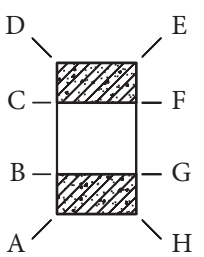

FIgURe 11: Number of longitudinal contour lines.

In Figure 12, the development of concrete cracking is shown, and in Figure 13, the failure forms of specimens are shown.

\subsection{Failure Characteristics}

(1) No matter how the LR ratio of shear key is, the areas where the test pieces are seriously damaged are located at the places where the shear key connects with the chords, which shows that the shear key is cut under the action of horizontal force. Continuously loading to the test piece after the shear key was horizontally cut, the chords neighboring to the shear key show numbers of inclined cracks (Figure 13(a) to 13(d)). Failure pattern does not change with the increase of the LR ratio of shear key, and the failure load of all specimens does not increase with the increase of LR ratio of shear key.

(2) The location where the shear key connects with the upper surface of left-hand bottom chord and the lower surface of right-hand top chord is pulled apart along the direction of chord width under the action of the bending moment (Figure 13(e)). The location where the shear key connects with the lower surface of right-hand bottom chord and the upper surface of left-hand top chord is crushed along the direction of chord width under the action of the compressionflexure (Figure 13(f)).

(3) No crack development is observed on the front, back, left, and right sides of the shear key, indicating that the area where the chords connect with shear key is the weak zone.

The failure bearing capacity of all specimens does not increase with the LR ratio of shear key, and the failure pattern does not change with the increase of the ratio. The reason is likely to be as follows: The vertical height of shear key is requested to be less than or equal to its cross section size; namely, shear key is a block joint, the influence of the bending deformation is small, and hence, the LR ratio of shear key playing an important role under the action of bending moment cannot change the failure pattern. The 


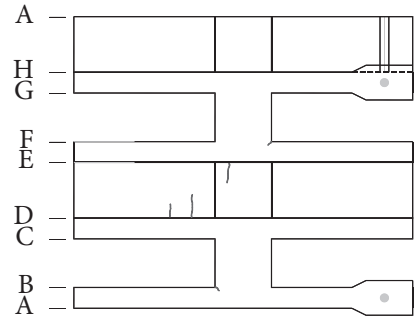

(a)

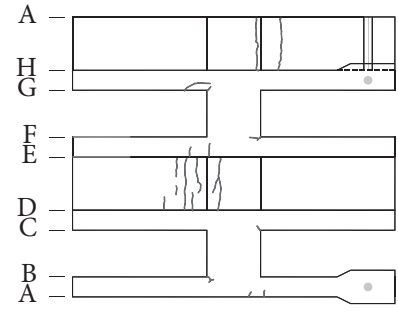

(b)

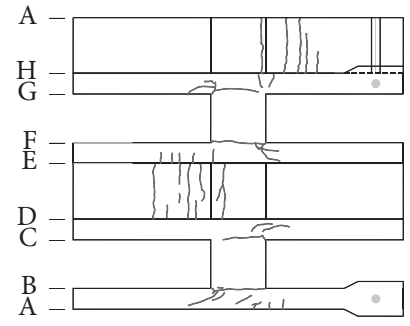

(c)

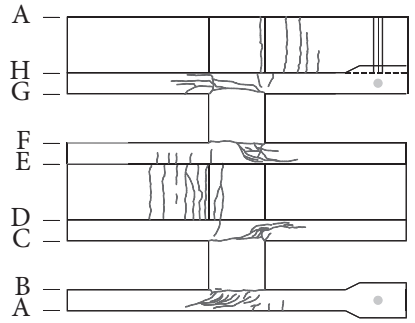

(d)

FiguRE 12: Cracking diagram of fracture development process. Crack distribution under (a) loading at 35\%, (b) loading at 55\%, (c) loading at $75 \%$, and (d) under loading at the failure load.

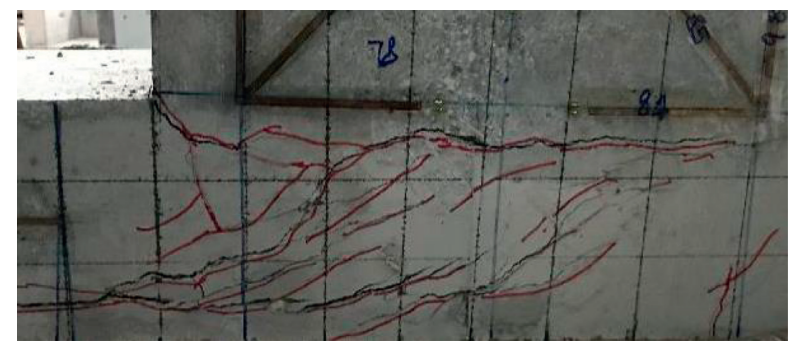

(a)

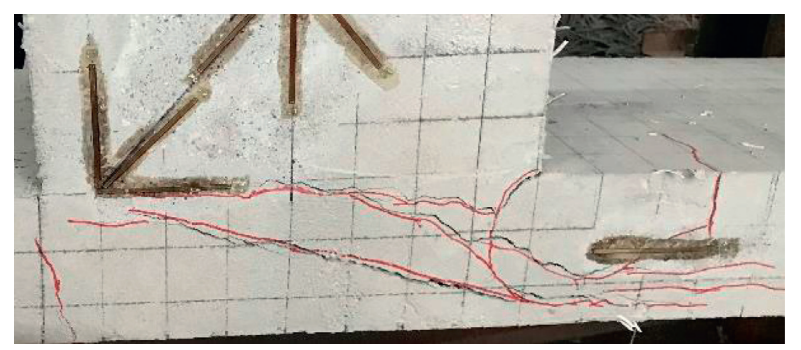

(c)

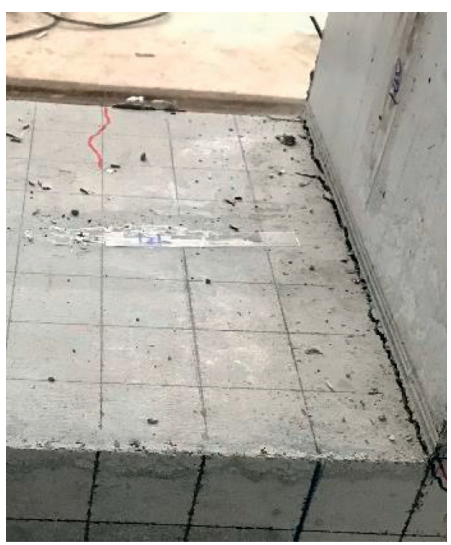

(e)

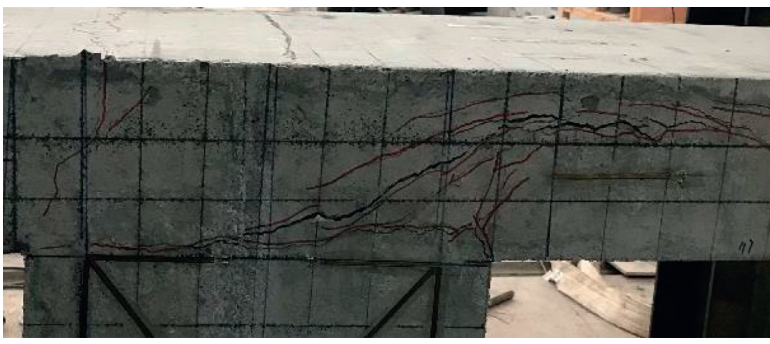

(b)

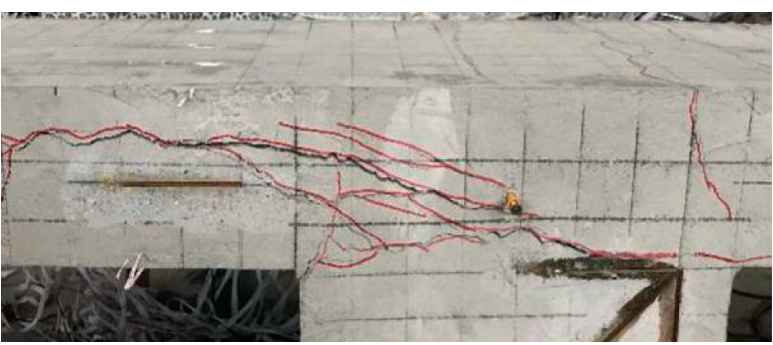

(d)

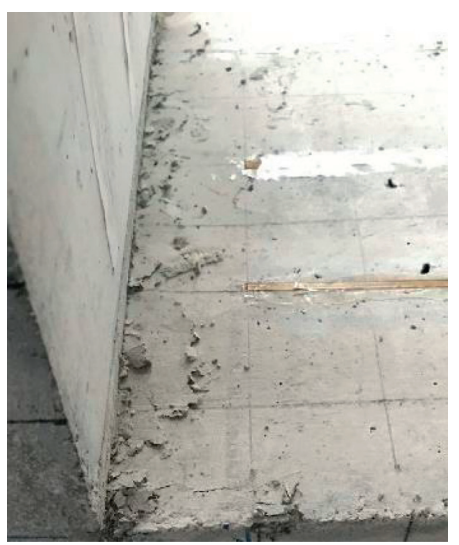

(f)

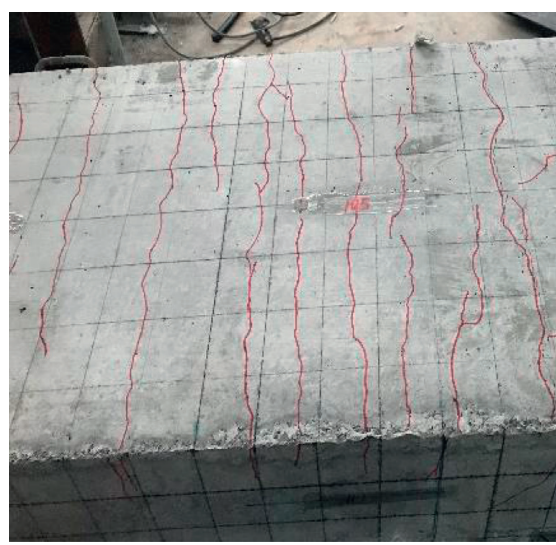

(g)

FIgURE 13: The failure form diagram. The cracks at the location where the shear key on the front of the test piece connects with the (a) bottom chord and (b) top chord. The cracks at the location where the shear key on the back of the test piece connects with the (c) bottom chord and (d) top chord. (e) The location where the left side of shear key connects with bottom chords is pulled apart. (f) The location where the right side of shear key connects with bottom chords is crushed. (g) The cracks at the location of the upper surface of the top chord. 
failure is determined by the development cracks of shear key-chords connection area.

\section{Experimental Results and Analysis}

In this paper, the time when the LR strain of shear key reaches the yield strain value or significant turning point occurs on the load-displacement curve is taken as the yield condition of the test pieces, and the time when no more load increase is possible is taken as the failure moment of the test pieces.

\subsection{Strain of LR, Concrete, and Stirrup of the Shear Key}

4.1.1. Strain of LR and Concrete. According to the test, when the specimen is failure, the average strain values of the measuring points 4,8 , and 12 of group 1 , group 2 , and 3 -C of group 3 are greater than the yield strain values, while the average strain values of the same measuring points of 3-A and 3-B are less than the yield strain values. The load-strain curves of group 3 are drawn by using the average strain values of the measuring points 4,8 , and 12 , and the rest of the test pieces are drawn by selecting the yield strain measurement points. Figure 14 shows the load-strain curve of the LR on the left side of the shear key, where 1-C, 1-B, 2$\mathrm{B}$, and $2-\mathrm{C}$ are the data at measuring point $4 ; 1-\mathrm{A}$ and 2-A are the data at measuring point 12 . Figure 15 shows the loadstrain curve of the LR on the right side of the shear key, where $1-\mathrm{A}$ is the data at measuring point $13 ; 2-\mathrm{A}$ and $2-\mathrm{C}$ are the data at measuring point $17 ; 1-\mathrm{B}, 1-\mathrm{C}$, and $2-\mathrm{B}$ are the data at measuring point 21 . Figure 16-18 show the load-strain curves of concrete, respectively, at measuring points 34,37 , and 47.

In Figures 14 and 15, at the initial stage of loading, the strain of LR of shear key grows very slowly and the values are very small. When the load reaches $140 \mathrm{kN}$, the strain growth rate becomes faster. Meanwhile, the strain values of some specimens increase sharply after the load reaches $140 \mathrm{kN}$, probably for the concrete cracking near the longitudinal bar, and the force has been passed to longitudinal bar. When the load reaches about $75 \%$ of the failure load, the load growth rate becomes slow; the strain of LRs increases sharply, showing significant yielding characteristics. In case of loading continuously, after the ultimate load is reached, the load-strain curves of the LRs begin to fall, showing the failure of the test pieces. The strain value of LRs on the right side of shear key of most test pieces is $80 \%$ to $95 \%$ of that on the right side, showing that the transmission force of the test device is reliable.

In Figures 16 to 18 , at the initial stage of loading, the load-strain curves of concrete of the shear key grow approximately linearly, indicating that the test piece is at the stage of elastic stress. When the load reaches about $75 \%$ of the failure load, the load growth rate becomes slow. Continuing to load, after the ultimate load is reached, the loadstrain curves of the concrete begin to fall, showing the failure of the test pieces. The concrete strain values of test pieces 1-B and 3-C are significantly smaller than that of other test pieces; this may be possibly caused by sliding of a bearing position of this test piece. Probably for the fabrication error of 2-A, the strain value of No. 47 measuring point is obviously larger than that of other specimens, and the ultimate load is obviously smaller than that of other specimens.

The strain values of measuring points 34 and 47 near the shear key-chords connection area are obviously bigger than the values of measuring point 37 in the middle of shear key; this is mainly because the shear key-chords connection area is affected by shear force, bending moment, and axial force, while the middle of shear key is mainly affected by shear force.

Ignoring the influence of bending moment, the diagonal lines of $45^{\circ}$ and $135^{\circ}$ are the principal stress directions of shear keys. Referring to the concrete strain values of the shear key (shown in Figure 19), the strain values of measuring point 34 along the diagonal direction of the shear key are the largest, followed by the values of measuring point 33 along the horizontal direction, and the values of measuring point 35 along the vertical direction are the smallest, indicating that the direction along the diagonal of shear key can be approximately the direction of the principal compressive stress of the shear key.

4.1.2. Strain of Stirrup. The strain values and change tendency of shear key stirrups for various test pieces are similar. Figures 20 to 22 show the load-strain curves at measuring points 29 to 32 of test pieces 1-A, 2-A, and 3-A.

In Figures 20 to 22, the absolute values of stirrup strain increase with the load, but the values are small when the test pieces fail, showing that the stirrups of shear key are not subjected to big force; it mainly acts to fix the LRs, and the stirrups can be arranged according to constructional reinforcement. The strain values of measuring points 29 and 32 of test piece 1-A and measuring point 32 of test piece 3-A are bigger than those at other measuring points; the main reason is that the measuring points 29 and 32 are in the area where the shear key connects with chords, and the area is under the composite stress state. The strain of the measuring points can be divided into tension and pressure; this may be possibly caused by the strain gauges that are affected by the surrounding concrete particles.

4.2. Load-Displacement Curve. The absolute values of $y-2$ and $y-3$ displacements of the displacement meters are roughly equal; the horizontal displacement of test pieces can be obtained by subtracting the $y-2$ value from the $y-1$ value of the displacement meter. The load-displacement curves in horizontal direction of 3 groups are given below as shown in Figure 23.

In Figure 23, prior to cracking, the displacement of various test pieces develops slowly; the relationship between displacement and load is approximately linear; this indicates that the test pieces are at elastic working state; after cracking and before yielding, the slopes of curves of various test pieces reduce gradually; this is because the cracking with the chord weakens the overall lateral stiffness of the test pieces and makes the curve gradually slow down; after the test pieces yield, the displacement increases quickly with the 


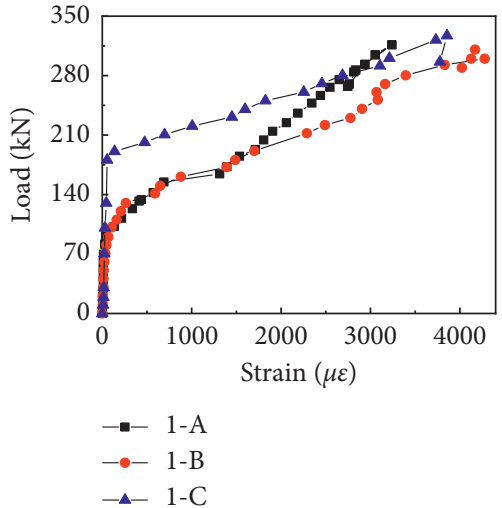

(a)

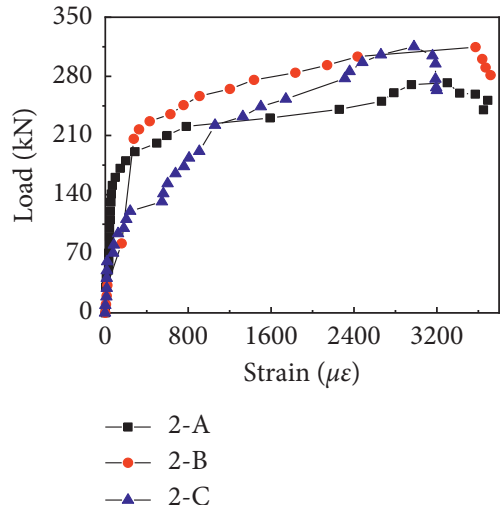

(b)

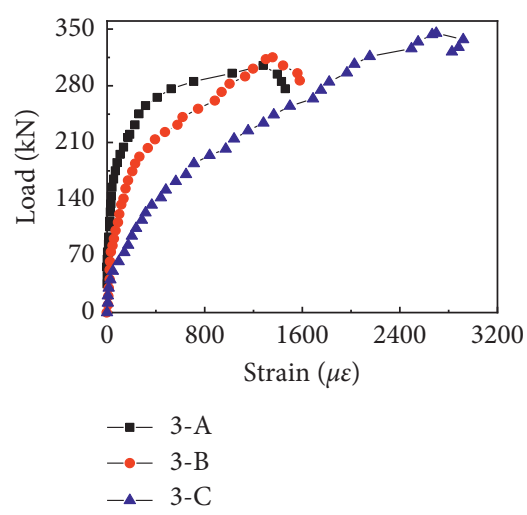

(c)

FIGURE 14: Load-strain curves of LR on left side of the shear key. (a) First group. (b) Second group. (c) Third group.

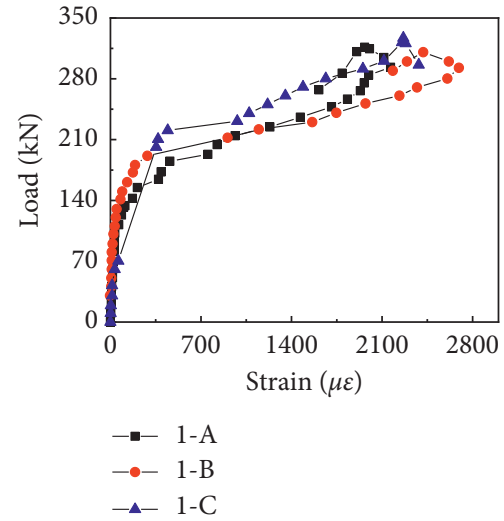

(a)

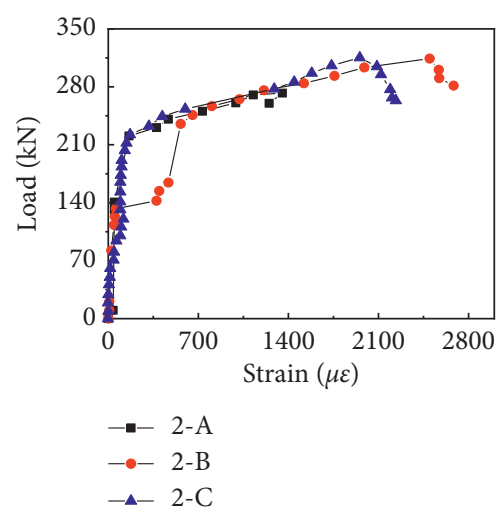

(b)

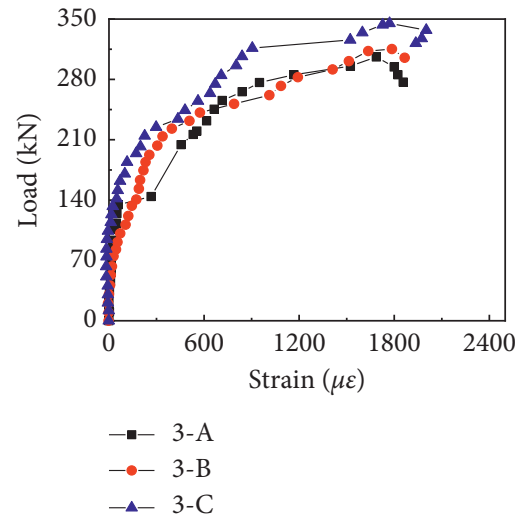

(c)

FIGURE 15: Load-strain curves of LR on right side of the shear key. (a) First group. (b) Second group. (c) Third group.

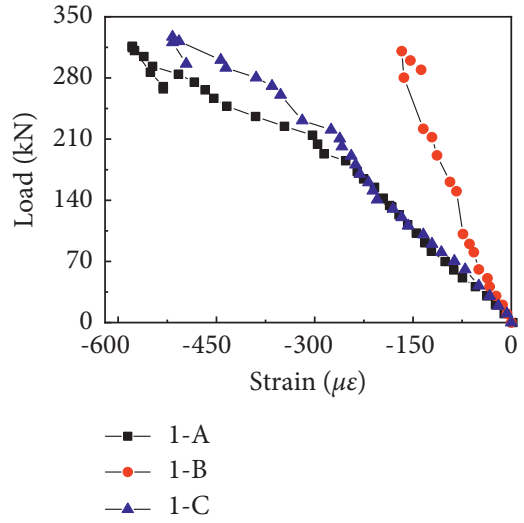

(a)

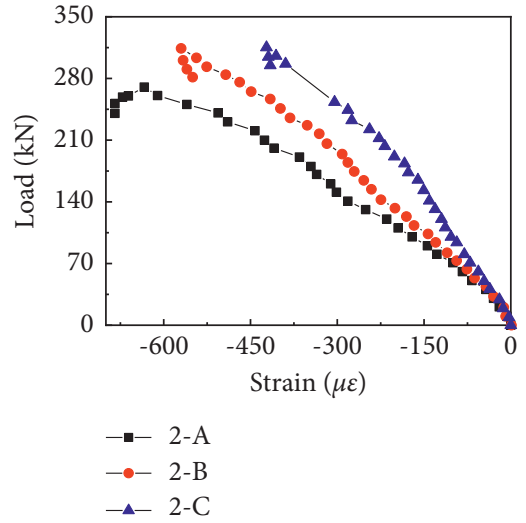

(b)

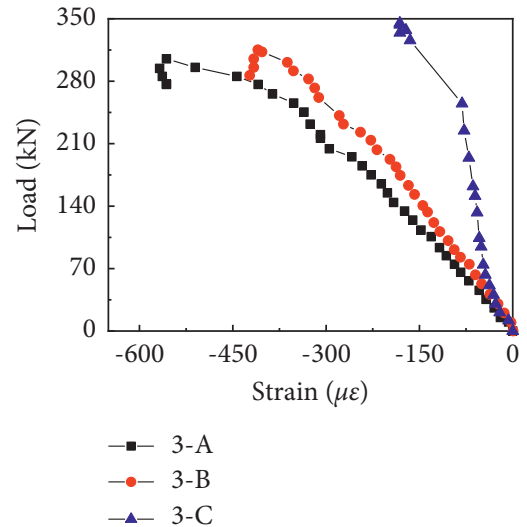

(c)

FIgURE 16: Load-strain curves of No. 34 measuring point on the front of the shear key concrete. (a) First group. (b) Second group. (c) Third group.

application of the load; the curves of the test pieces have smooth sections; this indicates that the test pieces have better deformation capacity; after the ultimate load is reached, the increase of loading becomes impossible; the displacement further increases and indicates that the test pieces failed. In fact, curve variation rule of Figure 23 is similar to that of other types of reinforced concrete members [26-28]. 


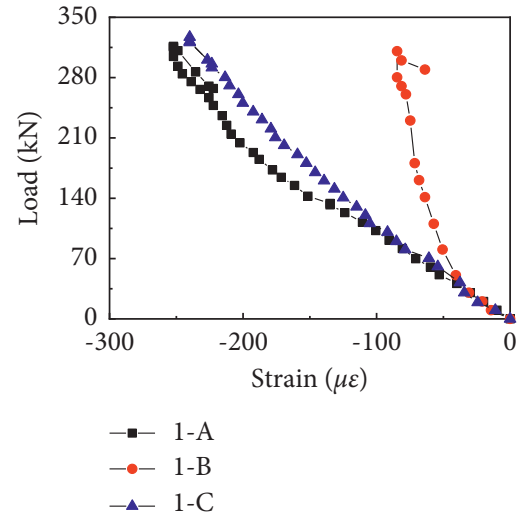

(a)

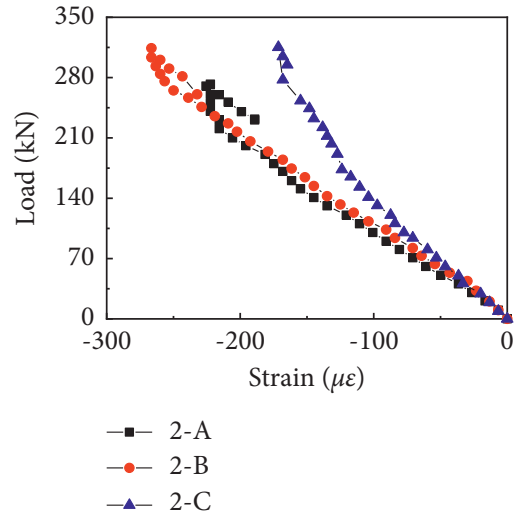

(b)

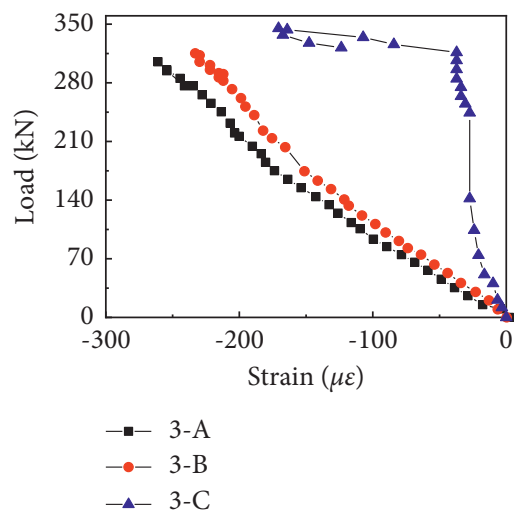

(c)

Figure 17: Load-strain curves of No. 37 measuring point. (a) First group. (b) Second group. (c) Third group.

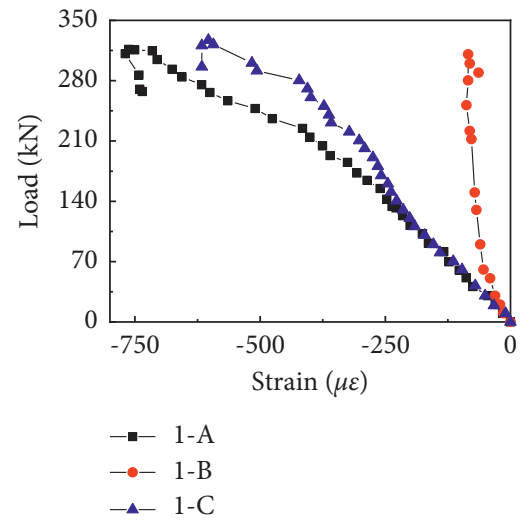

(a)

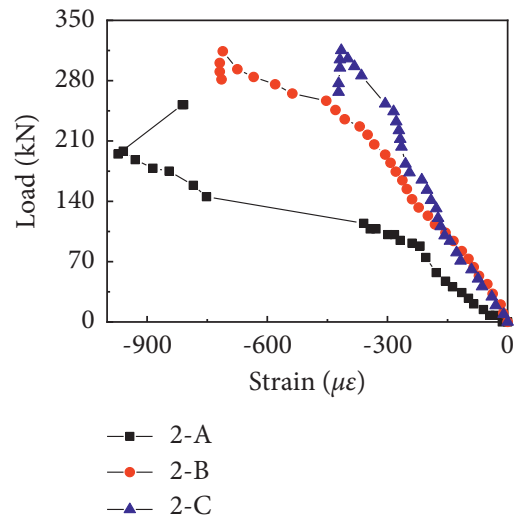

(b)

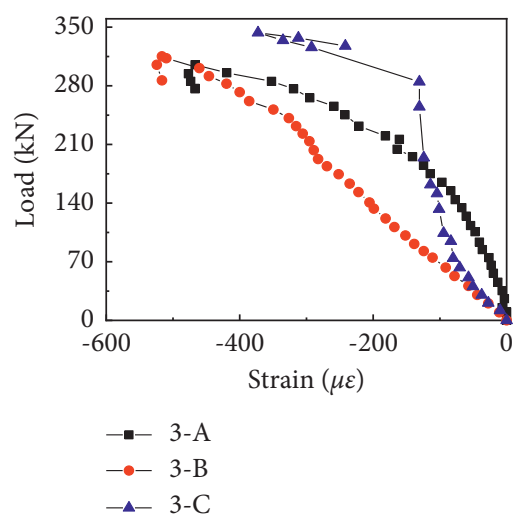

(c)

FIGURE 18: Load-strain curves of No. 47 measuring point. (a) First group. (b) Second group. (c) Third group.

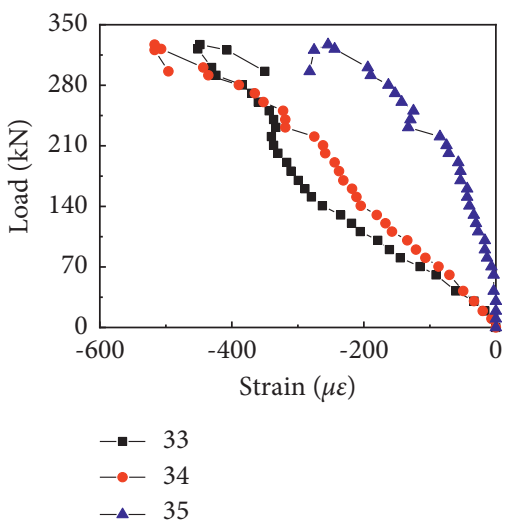

(a)

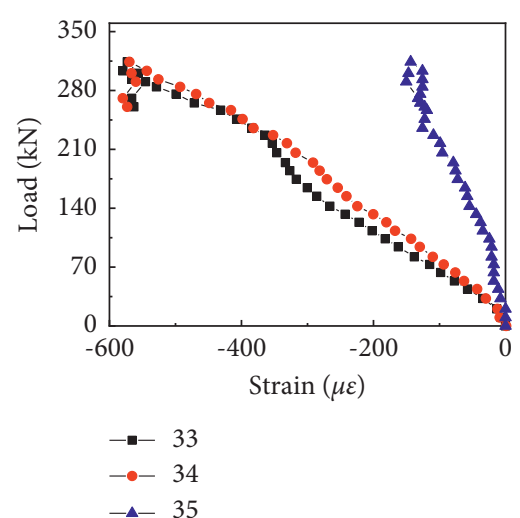

(b)

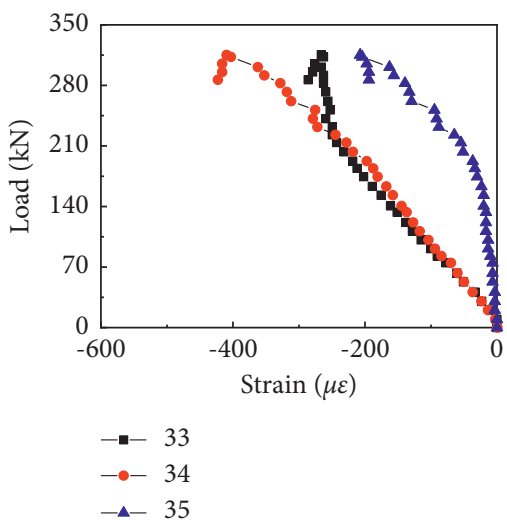

(c)

FIgURE 19: Load-strain curves of Nos. 33 35 measuring points. (a) 1-C. (b) 2-B. (c) 3-B.

At failure, the average strain values of the measuring points 4,8 , and 12 of group 1 and group 2 are greater than the yield strain values, while the average strain values of 3-A and 3-B are less than the yield strain values. The yield load of group 1 and group 2 is corresponding to the loads when the strain values in Figures 14(a)-14(b) reach the yield strain values. The yield load of group 3 is corresponding the loads when the significant turning point occurs on the load- 


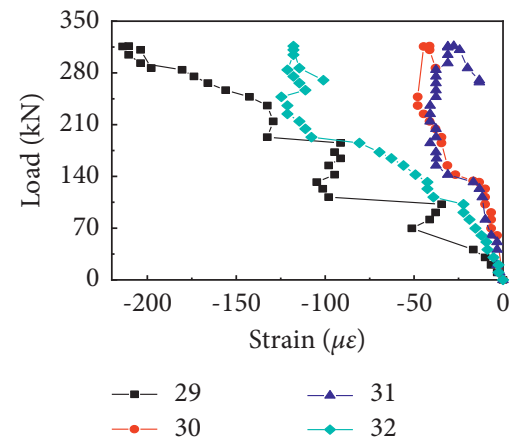

FIgURE 20: Load-strain curves at measuring points 29 to 32 of test piece 1-A.

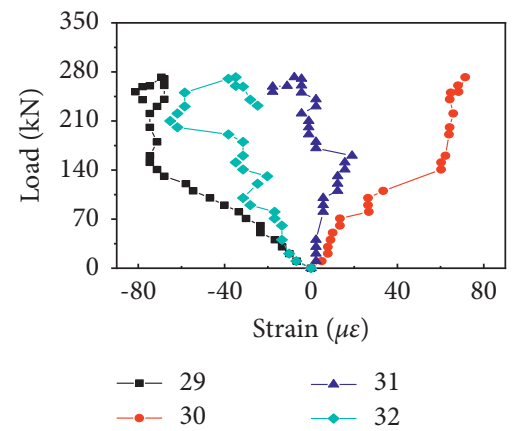

Figure 21: Load-strain curves at measuring points 29 to 32 of test piece 2-A.

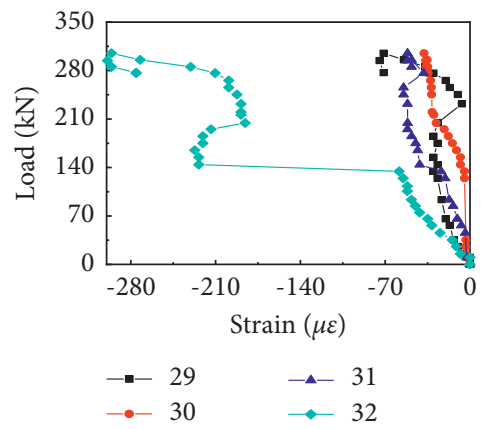

Figure 22: Load-strain curves at measuring points 29 to 32 of test piece 3-A.

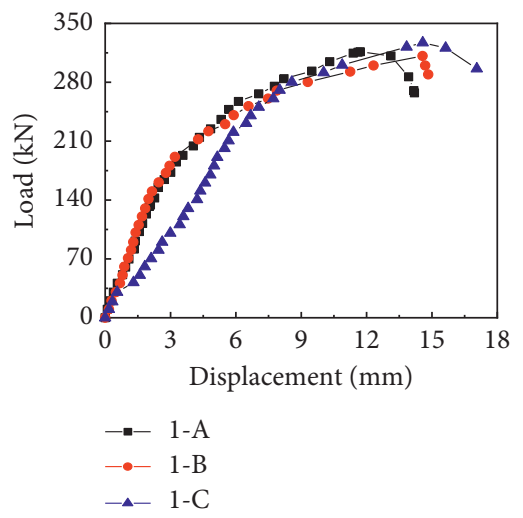

(a)

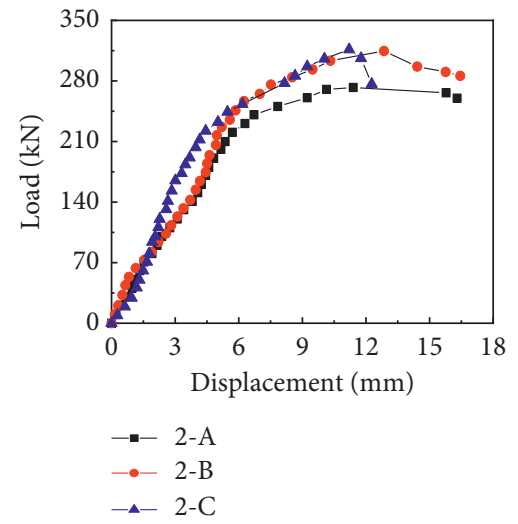

(b)

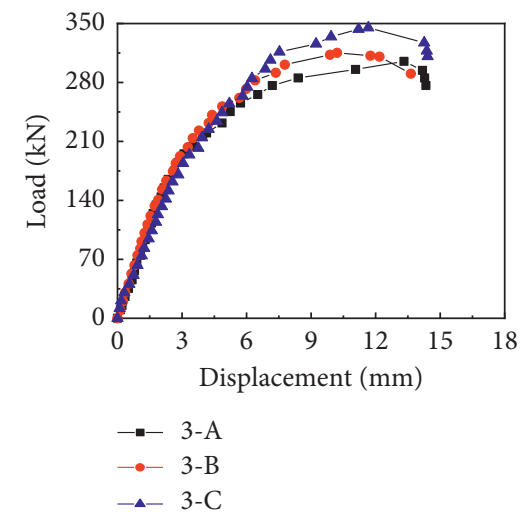

(c)

FIGURE 23: Load-displacement curves. (a) First group. (b) Second group. (c) Third group. 
displacement curve in Figure 23. In this paper, the corresponding load at the yield of the test pieces is taken as the yield load $V_{y}$; the corresponding displacement is yield displacement $\Delta_{y}$; maximum load value during loading is called ultimate load $V_{u}$, the corresponding displacement is called ultimate displacement $\Delta_{u}$, and the corresponding values are given in Table $4 . V_{y}$ increases with the LR ratio of shear key; the ultimate load $V_{u}$ does not increase with the LR ratio of shear key; it can be judged by combining with the abovementioned experimental phenomena that the final failure of the test pieces is controlled by the degree of crack development of shear key-chords connection area and has no relationship with the LR ratio of shear key.

\section{Computation of Shear Bearing Capacity}

In the computation as follows, the measured values in $\mathrm{Ta}$ bles 2 and 3 are converted to design strength [29]:

$$
\begin{aligned}
f_{y} & =\frac{f_{\mathrm{yk}}}{1.1} \\
f_{c} & =0.6286 \alpha_{c 1} \alpha_{c 2} f_{\mathrm{cu}, k}, \\
E_{c} & =\frac{10^{5}}{2.2+34.7 / f_{\mathrm{cu}, k}}, \\
f_{\mathrm{tk}} & =0.88 \times 0.395 f_{\mathrm{cu}, k}^{0.55}(1-1.645 \delta)^{0.45} \times \alpha_{c 2}, \\
f_{t} & =\frac{f_{\mathrm{tk}}}{1.4},
\end{aligned}
$$

where $\alpha_{c 1}$ is the ratio of prism strength to cube strength, C50 and less take 0.76, C80 takes 0.82, and the intermediate is linear interpolation; $\alpha_{c 2}$ is the brittleness reduction coefficient of concrete, C40 and less take 1.0, C80 takes 0.87, and the intermediate takes linear interpolation; $\delta$ is variation coefficient of compressive strength of concrete cube block.

\subsection{Computational Method of Shear Bearing Capacity and} Discussion. At present, it is considered that the stress pattern of the shear key is similar to the reinforced concrete corbel. The concrete of shear key is mainly compressed, that is, similar to the corbel belly concrete, and the LRs of shear key are mainly tensile, that is, similar to the corbel LRs. The corresponding calculation formula and the calculation diagram (see Figure 24) are put forward [30].

The calculation formula controlled by the cracks of shear key is as follows:

$$
V_{k}=0.8 \frac{f_{\mathrm{tk}} b h_{0}}{0.5+a / h_{0}} .
$$

The diagram and formula for calculating the shear bearing capacity of current algorithm are given as follows:

$$
V \leq \frac{0.85 A_{S} f_{y} h_{0}}{a} \text {. }
$$

In diagram, $V\left(V_{k}\right)$ is the bigger one among the axial force between top chords and bottom chords, $a$ is the distance from the bottom chord centroid axis to the bottom surface of the top chord, $b$ is the width of the shear key cross section, $h$ is the height of shear key cross section, $h_{0}$ is the effective height of shear key cross section, $a_{s}$ is the distance from the position where the resultant force of LR for shear key acts to the edge of the concrete, $l_{n}$ is the height of shear key in vertical direction, $h_{1}$ is the height of bottom chord, and $h_{2}$ is the height of top chord. $A_{\mathrm{s}}$ is the area of single side LR of the shear key, and the ratio of single side is requested to be equal to or larger than the values of $0.2 \%$ and $0.45 f_{t} / f_{y}$, the minimum LR ratio of the shear key cross section is $0.6 \%, f_{y}$ is the yield strength of LR of shear key, and $f_{t k}$ is concrete axial tensile strength standard value.

According to test phenomena, the load of test specimens when oblique cracks appear at the area where the shear key connects the chords is about 140 to $165 \mathrm{kN}$, and the shear bearing capacity of specimens calculated by formula (6) is $149 \mathrm{kN}$, and the relative error is $6 \%$ to $11 \%$, so formula (6) can accurately predict the corresponding load when oblique cracks appear at the connection of shear key-chord.

In Figures 14 and 15, the strain values of the LRs are very small before the concrete cracking at the shear key-chords connection area. However, after cracks appear in this area, the LRs strain of shear key increases sharply. In Figures 15 to 18 , the shear key concrete is mainly under compression, and the strain values along the diagonal direction are the largest, so the following can be concluded:

(1) Before concrete cracking at shear key-chords connection area, the load mainly acts on the concrete. When the load reaches the value calculated by formula (6), the LRs of shear key begin to resist the external force and are mainly subjected to tensile force.

(2) Ignoring the tensile strength of shear key concrete, it can be approximately considered that the shear key along a diagonal direction is the direction of the principal compressive stress.

(3) In combination with (1) and (2), it can be known that the stress pattern of shear key under horizontal load is similar to that of reinforced concrete corbel, so the current theory is reliable.

The maximum average strain values of measuring points 4,8 , and 12 of 3 -A and 3 -B are $1460 \times 10^{-6}$ and $1580 \times 10^{-6}$, respectively, and are smaller than the corresponding yielding strain values. The shear bearing capacity of 3-A and 3-B should be calculated by the measured strain values, and the other test pieces can be calculated by taking the LR stress of shear key as $f_{y}$. The shear bearing capacity values of test pieces computed by formula (7) are defined as $V_{1}$, the values of group 1, group 2, and 3-C in group 3 are $109 \mathrm{kN}, 180 \mathrm{kN}$, and $297 \mathrm{kN}$, respectively, and the values of 3-A and 3-B are $205 \mathrm{kN}$ and $222 \mathrm{kN}$ in turn. Comparing the $V_{y}$ in Table 4 with the values calculated by formula (7), the shear bearing capacity of group 1 (ratio is $0.49 \%$ ) and group 2 (ratio is $0.82 \%$ ) computed by formula (7) is obviously smaller than 
TABLE 4: Main test results.

\begin{tabular}{|c|c|c|c|c|c|c|c|c|c|c|}
\hline Specimen number & & $1-\mathrm{A}$ & $1-\mathrm{B}$ & $1-\mathrm{C}$ & $2-\mathrm{A}$ & $2-B$ & $2-\mathrm{C}$ & $3-\mathrm{A}$ & $3-\mathrm{B}$ & $3-\mathrm{C}$ \\
\hline \multirow{2}{*}{ Yield load $V_{y}(\mathrm{kN})$} & Test value & 224 & 225 & 246 & 238 & 285 & 265 & 266 & 283 & 296 \\
\hline & Average value & & 232 & & & 263 & & & 282 & \\
\hline \multirow{2}{*}{ Yield displacement $\Delta \mathrm{y}(\mathrm{mm})$} & Test value & 4.73 & 5.09 & 6.94 & 6.64 & 5.84 & 6.11 & 6.52 & 6.40 & 6.87 \\
\hline & Average value & & 5.59 & & & 6.20 & & & 6.60 & \\
\hline \multirow{2}{*}{ Ultimate load $V_{u}(\mathrm{kN})$} & Test value & 318 & 311 & 327 & 272 & 315 & 316 & 306 & 316 & 345 \\
\hline & Average value & & 318 & & & 301 & & & 322 & \\
\hline \multirow{2}{*}{ Ultimate displacement $\Delta_{u}(\mathrm{~mm})$} & Test value & 12.60 & 14.69 & 14.58 & 11.29 & 13.20 & 11.21 & 14.08 & 10.69 & 14.17 \\
\hline & Average value & & 13.96 & & & 11.90 & & & 12.98 & \\
\hline
\end{tabular}

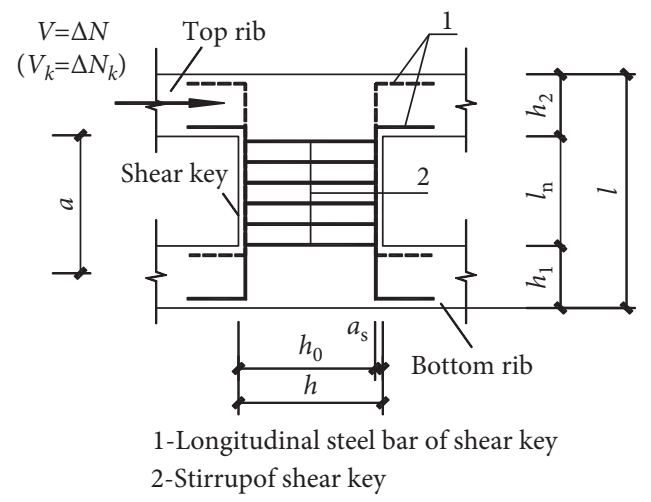

FIGURE 24: Schematic diagram of shear bearing capacity computation of key shear.

the corresponding values of $V_{y}$, and the value of 3-C (ratio is $1.24 \%)$ is bigger than the corresponding value $V_{y}$, while the values of 3-A and 3-B are less than the corresponding $V_{y}$.

In engineering application, the yield bearing capacity is taken as the design value of bearing capacity. It can be obtained from the comparison results between formula (7) and the test: when the LR ratio of shear key is $0.49 \%$ and $0.82 \%$, the results calculated by formula (7) are conservative and safe for engineering application, while when the ratio is $1.24 \%$, the results calculated by formula (7) are probably bigger than the yield values and not safe for engineering application. It can be speculated that, for test specimens, if the LR ratio of shear key is greater than $1.24 \%$, the results calculated by formula (7) may be larger than the ultimate shear capacity, which is obviously unsafe. This is because the shear capacity calculated by formula (7) will increase with the LR ratio of shear key, neglecting the fact that the final failure is controlled by the degree of concrete crack development at shear key-chords connection area and almost has no relationship with the LR ratio of shear key. So, to avoid formula (7) overestimating the shear capacity of shear key, a calculation formula based on the joint size to limit the maximum shear bearing capacity of shear key should be proposed.

5.2. The Restricted Condition of Shear Section. Based on the failure pattern, the shear key is cut along its cross section, the ultimate shear capacity has almost no relationship with the LR ratio of shear key, and the relative errors are large between the results of formula (7) and the test. It can be concluded that the ultimate shear bearing capacity of shear key is determined by the size of chords and shear key and the strength of concrete. The ratio of the vertical height $l_{n}$ of shear key to the cross section height $h$ is generally required to be less than or equal to 1 [1]; the shear key is a deep flexural member that is placed vertically.

In Chinese code, the single span reinforced concrete deep flexural member is shown in Figure 25, and the $l / h$ is requested to be less than 5 .

The restricted condition of shear section of the reinforced concrete deep flexural member is shown as

$$
V \leq \frac{1}{60}\left(10+\frac{l}{h}\right) \beta_{c} f_{c} b h_{0} .
$$

In formula (8), the $h_{0} / b$ is required to be less than or equal to 4 , where $V$ is the shear bearing capacity design value; $l$ is the calculation span and is required to be not less than $2 h$; $h$ is the height of cross section; $h_{0}$ is the effective height of cross section; $b$ is the width of cross section; $\beta_{c}$ is the concrete strength influence coefficient, C50 and less take 1.0, C80 takes 0.8 , and between C50 and C80 is linear interpolation; $f_{c}$ is concrete axial compressive strength design value, to test pieces; it can be computed according to formula (2);

The shear key joint is integrated with the top and bottom chords; the shape is different from the reinforced concrete deep flexural member shown in Figure 25. According to the test, after the shear key is cut along the cross section, the load can continue to increase, and the concrete cracks of top and bottom chords near shear key develop quickly. It can be concluded that the cross section size of chords has effect on 


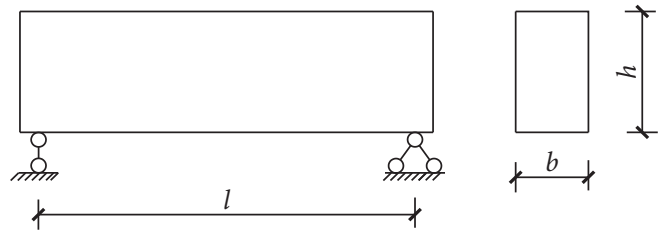

FIgURE 25: Schematic diagram of the single-span deep flexural member.

shearing bearing capacity. In engineering applications, the cross section widths of chords and shear key are equal. Therefore, the effect of chords on shearing bearing capacity can be approximately considered as the effect of cross section height of chords, and taking the value of $l / l_{n}$ to consider the effect of chords, the restricted condition of shear section of shear key is given as follows:

$$
V \leq \frac{1}{60} k\left(10+\frac{l}{l_{n}}\right) \beta_{c} f_{c} b h .
$$

$k$ is the introduced shear bearing capacity correction factor, taking $k$ as 0.53 for matching the load that the concrete is crushing at the shear key-chords; $b, h, l$, and $l_{n}$ have the same meanings as $5.1 . l / l_{n}$ represents the influence of the bottom and top chord dimensions on the formula; $\beta_{c}$, $f_{c}$ have the same meanings as formula (8).

The shear bearing capacity calculated by formula (9) is defined as $V_{2}$, and $V_{u}, V_{y}, V_{1}$, and $V_{2}$ of various groups of test pieces and their ratios are given in Table 5. The loading coefficient is defined as $\gamma_{u}$, and $\gamma_{u}=V_{2} / V_{u}$. The experimental phenomena reveal that the cut of shear key is almost simultaneous with the concrete crushing of shear key-chords connection area. So taking the concrete crushing of shear key-chords connection area as the mark of ultimate limited states, the corresponding $\gamma_{u}$ in Chinese code is 1.30 [31]. As shown in Table 5, $\gamma_{u}$ is 1.32 to 1.41 , indicating that the calculated results by formula (9) are safe. The relative error between $V_{y}$ and $V_{2}$ is $2 \%-24 \%$; this indicates that the calculated result of formula (9) is close to the yield values of the test. The values of $V_{u} / V_{1}$ decrease with the increasing of the LR ratio of shear key. If the LR ratio of shear key is larger than the value in group 3, the values of $V_{u} / V_{1}$ are likely smaller than 1 for the ultimate shearing bearing capacity controlled by the degree of concrete cracking development in connection area.

\section{Finite Element Analysis (FEA)}

6.1. Introduction of FEA. In finite element analysis, the solid unit element is applied to simulate the concrete and the link 8 element is adopted to simulate the steel bar $[32,33]$. The solid unit element can achieve both cracking and crushing of the concrete material. The failure criterion of the concrete is employed by the William and Warnke five-parameter criterion [34] and the shear transfer coefficients for an open and closed crack are 0.2 and 0.2 , respectively [35]. The Bilinear Isotropic Hardening is used to simulate the nonlinear behavior of the reinforcement [36]. Poisson's ratio of concrete and steel is 0.2 and 0.3 , respectively [29]. The displacement is taken as the criterion of convergence.
The mechanical property parameters of concrete and reinforcement are calculated by converting them into design values based on the results of Tables 2 and 3. The constraint and loading mode of FEA is the same as the test specimens. By considering that the shear key-chords connection area is at combined stress state, the failure of the test pieces can be determined according to the strength theory. In the test, the concrete along the width of shear key-chords connection area is crushed or pulled apart when loading to about $75 \%$ of the ultimate load, taking the third principal stress of concrete at the shear key-chords connection area $\sigma_{3}=f_{c}$ as the criterion to judge the failure of test pieces, named as failure mark 1. Meanwhile, to compare the yielding loads of FEA and test when the stress values of LR of shear key reach $f_{y}$, the stress of LR of shear key reaches $f_{y}$ as the second mark of failure, named as failure mark 2 . The results of failure marks 1 and 2 should be calculated separately.

6.2. Results of FEA. The finite element (FE) models are distinguished using the prefix "FE" followed by the group numbers 1, 2, and 3, respectively. The pictures of model are displayed in Figure 26.

The results of FEA and its ratio to the values in Tables 4 and 5 are shown in Table 6:

6.2.1. Results under Failure Mark 1. The shear bearing capacity of FE1, FE2, and FE3 is almost equal; namely, the shear bearing capacity has no relation with the reinforcement ratio of shear key. The values of $V / V u$ are $0.71-0.76$. In the experiment, when concrete in the connection area is crushed (compressive stress attained $f_{c}$ ), the corresponding load is only approximately $75 \%$ of the ultimate load. So, the shearing bearing capacity of FEA and test matches well. The stress distribution of steel bars of FE models is shown in Figure 27. In Figure 27(a), the maximum tensile stress of LRs of shear key is close to the yield strength, while the values of FE2 and FE3 in Figures 28(b) and 28(c) are smaller than the corresponding yield strength, and the results are also consistent with the load-strain curves in Figure 14.

For FE1-FE3, the relative errors of $V$ and $V_{y}$ are within $20 \%$, indicating that the shear bearing capacity calculated by FEA is in good agreement with the yield shearing bearing capacity of test. When the FE models failed, the distribution of concrete cracks and crushing and the compressive stress of FE1-FE3 are similar. Figures 28 and 29 show the distribution of concrete cracks and crushing and the third principal compressive stress of FE3 at failure, respectively.

In Figure 28, the cracks and crushing mainly distribute in the shear key-chords connection area, which are consistent 
TABLE 5: Shear bearing capacity and its ratio.

\begin{tabular}{lccccccc}
\hline Group number & $V_{u} / \mathrm{kN}$ & $V_{y} / \mathrm{kN}$ & $V_{1} / \mathrm{kN}$ & $V_{2} / \mathrm{kN}$ & $V_{u} / V_{1}$ & $V_{u} / V_{2}$ & $V_{y} / V_{1}$ \\
\hline First group & 318 & 232 & 109 & & 2.84 & 1.39 & 2.13 \\
Second group & 301 & 263 & 180 & 228 & 1.63 & 1.32 & 1.46 \\
Third group & 322 & 282 & 297 & & 1.08 & 1.41 & 0.95 \\
\hline
\end{tabular}

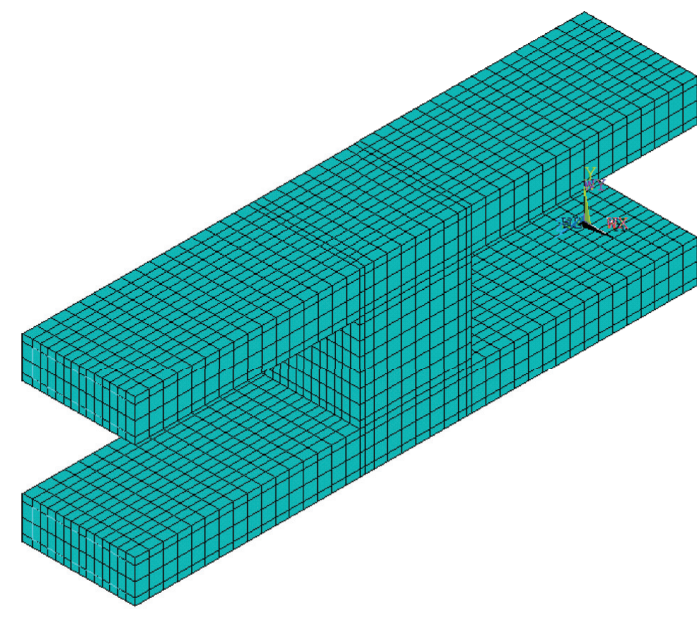

(a)

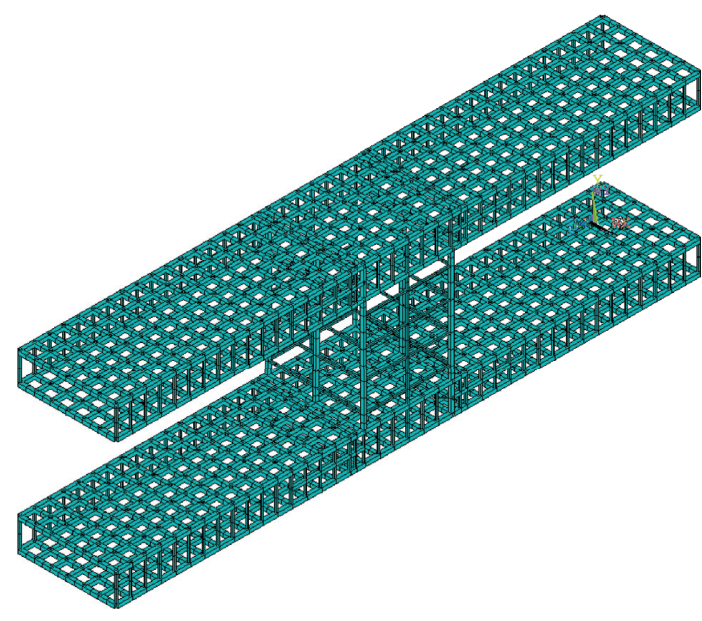

(b)

Figure 26: Finite element model diagram. (a) Model diagram. (b) Skeleton diagram of steel bar.

TABLE 6: The results of FEA and its ratio to the values in Tables 4 and 5.

\begin{tabular}{|c|c|c|c|c|}
\hline \multirow{2}{*}{ Failure mark } & \multirow{2}{*}{ Results of FEA and its ratio to the values in Tables 4 and 5} & \multicolumn{3}{|c|}{ Model number (group number) } \\
\hline & & FE1 (group 1) & FE2 (group 2) & FE3 (group 3) \\
\hline \multirow{5}{*}{ Failure mark 1} & The load of FEA $V / \mathrm{kN}$ & 225 & 228 & 228 \\
\hline & $V / V_{u}$ & 0.71 & 0.76 & 0.71 \\
\hline & $V / V_{y}$ & 0.97 & 0.87 & 0.81 \\
\hline & The horizontal deflection of FEA $\Delta / \mathrm{mm}$ & 3.80 & 3.68 & 3.55 \\
\hline & $\Delta / \Delta_{u}$ & 0.27 & 0.31 & 0.27 \\
\hline \multirow{5}{*}{ Failure mark 2} & The load of FEA $V / \mathrm{kN}$ & 240 & 306 & 372 \\
\hline & $V / V_{u}$ & 0.75 & 0.98 & 1.16 \\
\hline & $V / V_{y}$ & 1.03 & 1.16 & 1.32 \\
\hline & The horizontal deflection of FEA $\Delta / \mathrm{mm}$ & 4.90 & 5.53 & 8.08 \\
\hline & $\Delta / \Delta_{u}$ & 0.35 & 0.46 & 0.56 \\
\hline
\end{tabular}

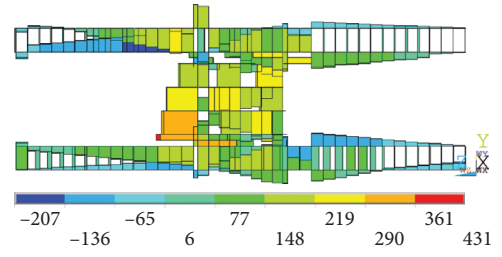

(a)

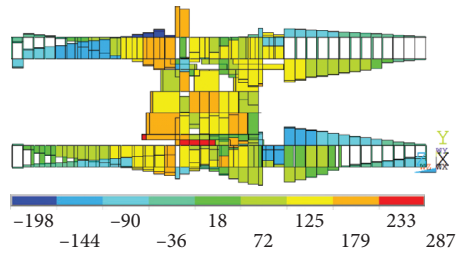

(b)

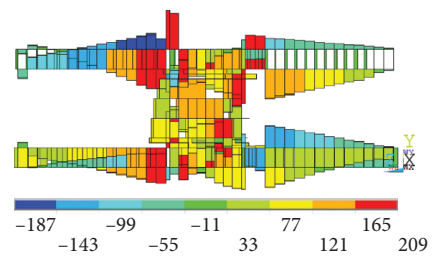

(c)

FIGURE 27: The stress distribution of steel bar under failure mark 1. (a) The steel bar of FE1. (b) The steel bar of FE2. (c) The steel bar of FE3.

with the distribution of test in Figures 12 and 13. In Figure 29, the maximum compressive stress of concrete appears at the shear key-chords connection area, which is consistent with the failure mode shown in Figure 13(f); the direction along the diagonal of shear key is the direction of the primary compressive stress of concrete, which is consistent with the experimental results in Figure 19. Combined with the above analysis, the FE models under failure mark 1 are reliable and the results of FEA have reference value. 


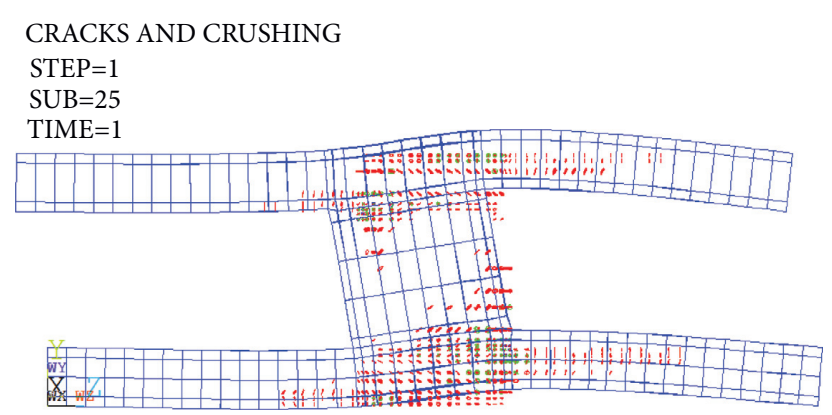

FIgURE 28: Cracks and crushing of concrete.

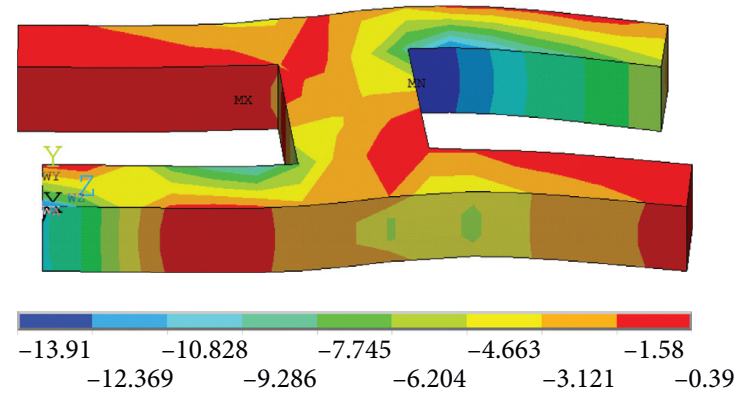

Figure 29: The third principal stress distribution.

6.2.2. Results under Failure Mark 2. The distribution of concrete cracks and crushing and the concrete compressive stress under failure mark 2 is similar to those in failure mark 1. Figure 30 shows the steel bar stress distribution of FE1FE3 under failure mark 2 .

In Figure 30, the tensile stress of the LR of shear key is larger than those in Figure 27, indicating that the yield of the LR of shear key is later than the crushing of concrete at the shear key-chords connection area, which is consistent with the test. In FE3, the LR of shear key cannot reach the yield strength for the little increasing of shear bearing capacity after the yielding of LR of chords, which is consistent with the results that the average strain values of LR of shear key in 3-A and 3-B do not yield. The shear bearing capacity $V$ of FE1 and FE2 is smaller than the $V u$ obtained from the test and the relative errors of $V$ and $V_{y}$ are $3 \%$ and $16 \%$, respectively. The shear bearing capacity $V$ of FE3 is larger than the $V_{y}$ and $V_{u}$ of test. So, the FEA is reliable under the small ratio of LR in shear key. Under large ratio of LR in shear key, the joint loses bearing capacity for the concrete crack development at shear key-chords connection area before the yielding of LR of shear key. Therefore, the shear bearing capacity of failure mark 2 under large ratio of shear key is larger than the ultimate shear capacity of joint.

The deformation shapes of FE1-FE3 are similar. The horizontal displacement of failure mark 1 is smaller than that of failure mark 2 for the concrete crushing at shear keychords connection is earlier than the yielding of LR in shear key. The deformation diagram of FE3 of failure marks 1 and 2 is shown in Figure 30, and the test deformation diagram is shown in Figure 31, and the deformations in Figures 30 and 31 match well.
The horizontal displacement value obtained by FEA is smaller than test displacement value; the main reasons are as follows: (1) there is an error with the test device, and (2) the failure of FEA is earlier than that of test specimens.

In conclusion, no matter how the ratio is, failure mark 1 can accurately predict the shear capacity corresponding to the crushing of concrete at shear key-chords connection area. Under small LR ratio of shear key, failure mark 2 can accurately predict the shear bearing capacity corresponding to the yielding of LR of shear key, but when the LR ratio of shear key is large, the result of failure mark 2 may be larger than the ultimate bearing capacity of specimen.

To further clarify the relationship between the shear bearing capacity of 2 failure marks and the LR ratio of shear key and the values of formulas (7) and (9), the models FE4 and 5 are added. In Figure 32, the shear bearing capacity of FE1-FE5 is compared with the formula results.

The shear bearing capacity of formula (9) is equivalent to the result of failure mark 1 , which does not increase with the LR ratio of shear key but is basically unchanged, indicating that formula (9) can accurately predict the crushing of concrete at shear key-chords connection area. The shear capacity calculated by formula (7) and failure mark 2 increases with the LR ratio of shear key. For formula (7), when the LR ratio of shear key is less than $1 \%$, the shear bearing capacity of formula (7) is smaller than that of formula (9) and failure mark 1; when the LR ratio of shear key is larger than $1 \%$, the shear bearing capacity of formula (7) is larger than that of formula (9) and failure mark 1. For failure mark 2 , when the LR ratio of shear key is less than $0.5 \%$, the shear bearing capacity of failure mark 2 is smaller than that of formula (9) and failure mark 1; when the LR ratio of shear 


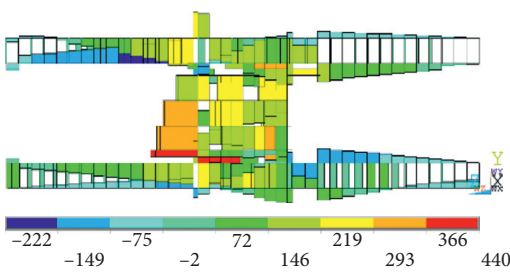

(a)

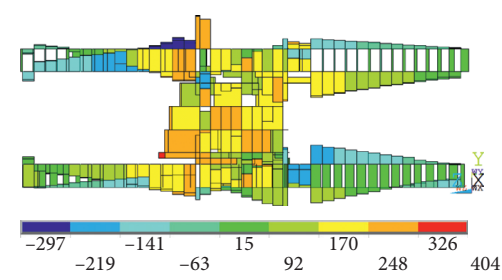

(b)
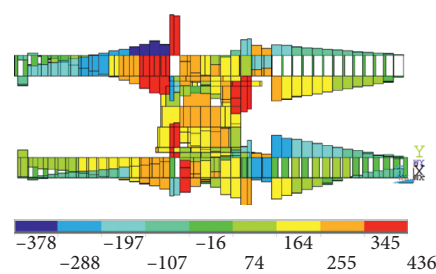

(c)

Figure 30: The steel bar stress distribution under failure mark 2. (a) The steel bar of FE1. (b) The steel bar of FE1. (c) The steel bar of FE1.

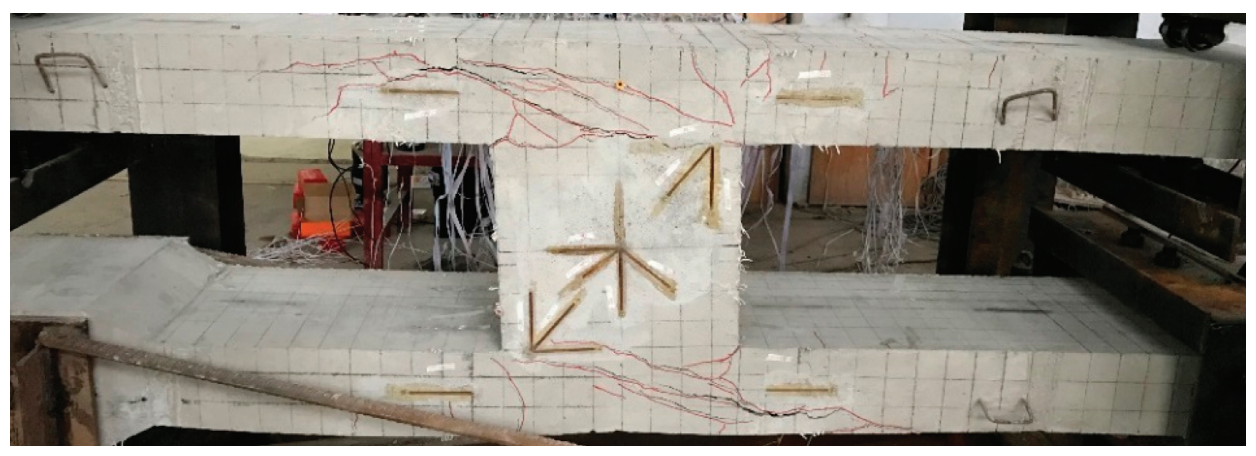

(a)

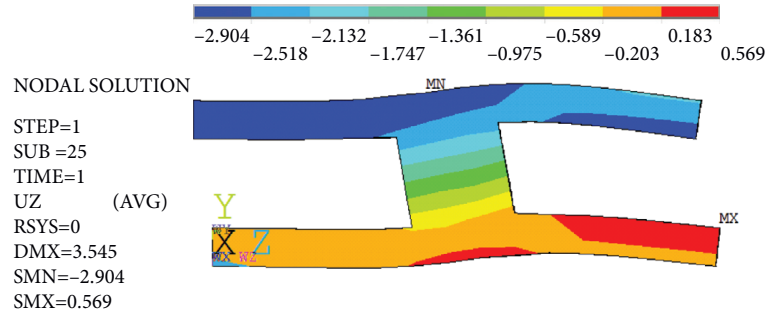

(b)

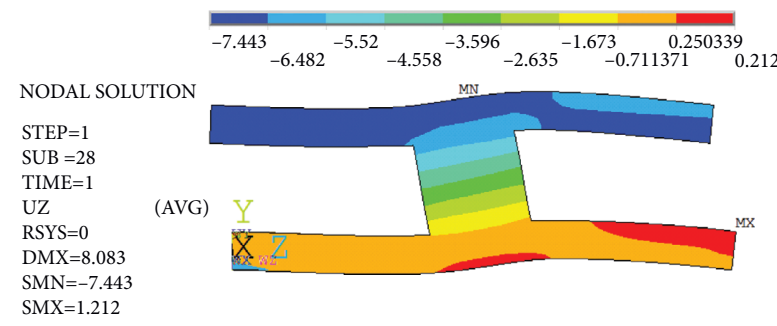

(c)

Figure 31: Deformation diagram. (a) Test deformation diagram. (b) Deformation diagram of FE3 under failure mark 1. (c) Deformation diagram of FE3 under failure mark 2.

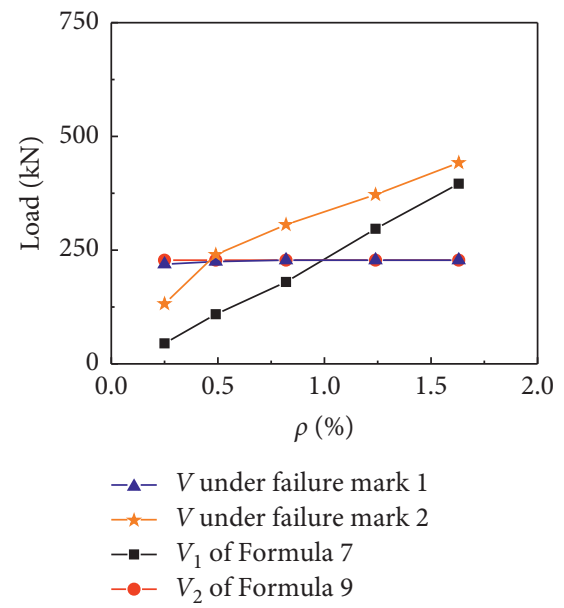

FIGURE 32: The shear bearing capacity of FEA and formula.

key is larger than $0.5 \%$, the shear bearing capacity of failure mark 2 is larger than that of formula (9) and failure mark 1. The test shows that the shear capacity of the joint can be increased by about $25 \%$ after concrete crushing at shear keychords connection area. For formula (7) and failure mark 2, when the LR ratio of shear key is larger than $1 \%$ and $0.5 \%$, 
TABle 7: Parameters of FE models.

\begin{tabular}{|c|c|c|c|c|c|c|}
\hline Model number & $b \times h\left(\mathrm{~mm}^{2}\right)$ & $b \times h_{1}\left(h_{2}\right)\left(\mathrm{mm}^{2}\right)$ & $l_{n}(\mathrm{~mm})$ & $L(\mathrm{~mm})$ & $\rho(\%)$ & Strength classes of concrete \\
\hline FE6 & $400 \times 400$ & $400 \times 150$ & 350 & 650 & 1 & $\mathrm{C} 30$ \\
\hline FE7 & $400 \times 400$ & $400 \times 150$ & 350 & 650 & 1 & C35 \\
\hline FE8 & $400 \times 400$ & $400 \times 150$ & 350 & 650 & 1 & $\mathrm{C} 40$ \\
\hline FE9 & $400 \times 400$ & $400 \times 150$ & 350 & 650 & 1 & $\mathrm{C} 45$ \\
\hline FE10 & $400 \times 400$ & $400 \times 150$ & 350 & 650 & 1 & $\mathrm{C} 50$ \\
\hline FE11 & $400 \times 400$ & $400 \times 150$ & 350 & 650 & 1 & C55 \\
\hline FE12 & $400 \times 400$ & $400 \times 150$ & 350 & 650 & 1 & $\mathrm{C} 60$ \\
\hline FE13 & $400 \times 400$ & $400 \times 150$ & 350 & 650 & 1 & C65 \\
\hline FE14 & $450 \times 450$ & $450 \times 275$ & 400 & 950 & $0 \%$ & $\mathrm{C} 30$ \\
\hline FE15 & $450 \times 450$ & $450 \times 275$ & 400 & 950 & $0.6 \%$ & $\mathrm{C} 30$ \\
\hline FE16 & $450 \times 450$ & $450 \times 275$ & 400 & 950 & $0.8 \%$ & $\mathrm{C} 30$ \\
\hline FE17 & $450 \times 450$ & $450 \times 275$ & 400 & 950 & $1 \%$ & C30 \\
\hline FE18 & $450 \times 450$ & $450 \times 275$ & 400 & 950 & $1.5 \%$ & $\mathrm{C} 30$ \\
\hline FE19 & $450 \times 450$ & $450 \times 275$ & 400 & 950 & $2 \%$ & C30 \\
\hline FE20 & $450 \times 450$ & $450 \times 275$ & 400 & 950 & $3 \%$ & C30 \\
\hline FE21 & $450 \times 450$ & $450 \times 275$ & 400 & 950 & $4 \%$ & C30 \\
\hline FE22 & $450 \times 450$ & $450 \times 275$ & 400 & 950 & $5 \%$ & C30 \\
\hline FE23 & $450 \times 450$ & $450 \times 275$ & 400 & 950 & $6 \%$ & $\mathrm{C} 30$ \\
\hline FE24 & $500 \times 500$ & $500 \times 350$ & 500 & 1200 & $1 \%$ & C30 \\
\hline FE25 & $500 \times 500$ & $500 \times 375$ & 450 & 1200 & $1 \%$ & $\mathrm{C} 30$ \\
\hline FE26 & $500 \times 500$ & $500 \times 400$ & 400 & 1200 & $1 \%$ & C30 \\
\hline FE27 & $500 \times 500$ & $500 \times 425$ & 350 & 1200 & $1 \%$ & $\mathrm{C} 30$ \\
\hline FE28 & $500 \times 500$ & $500 \times 450$ & 300 & 1200 & $1 \%$ & C30 \\
\hline
\end{tabular}

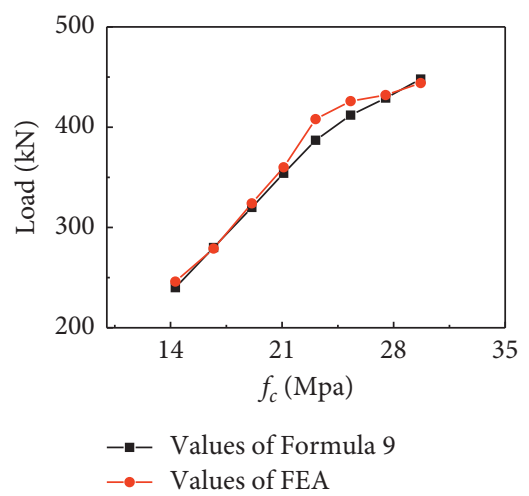

Figure 33: Values of formula (9) and FEA under changing of concrete strength (models FE6 to FE13).

respectively, the shear capacity of for formula (7) and failure mark 2 may be larger than the ultimate shear capacity of the joint.

For the safety and convenience of engineering application, the shear bearing capacity of joint can be calculated by formula (7), and to avoid formula (7) overestimating the shear bearing capacity of joint, the value of formula (7) needs to be smaller than the value of formula (9).

6.3. Parameter Analysis. To further verify the accuracy of formula (9), the parameterized analysis was carried out by taking the concrete strength, LR ratio of shear key, and the size of joint as parameter, taking the failure mark 2 as the failure of FE models.

In FEA, for the stirrup reinforcement ratio of chords and shear keys, the LR ratio of chords is the same as the test specimen, and the integral reinforcement model was adopted for the steel. The mechanical property parameters of concrete are taken as the design values specified in [29], the yield strength of the reinforcement is $360 \mathrm{MPa}$, and the elastic modulus is $2 \times 10^{5} \mathrm{MPa}$. The relevant parameters of the FE models are shown in Table 7.

The shear bearing capacity calculated by formula (9) and FEA are shown in Figures 33-35.

In Figure 33, the shearing bearing capacity increases with the strength of concrete, and when concrete strength changes from C30 to C65, the relative error of shear bearing capacity between the calculated values of formula (9) and the values of FEA is $0 \%-5 \%$. In Figure 34, when the reinforcement ratio is $0 \%$, the value of FEA is obviously smaller than the value of formula (9), and the relative error of shear bearing capacity between formula (9) and the FEA is $27 \%$; namely, formula (9) cannot be used when the LR ratio of 


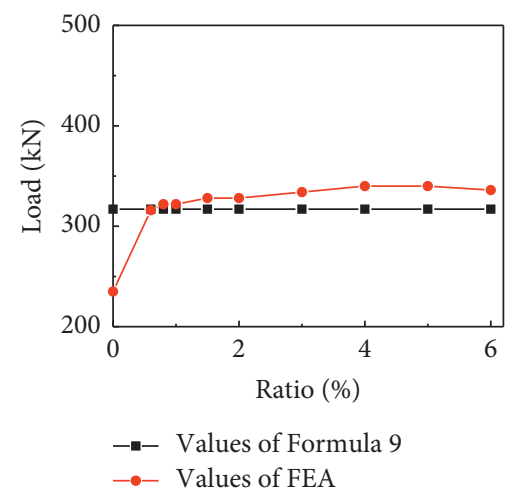

Figure 34: Values of formula (9) and FEA under changing of LR ratio of shear key (models FE14 to FE23).

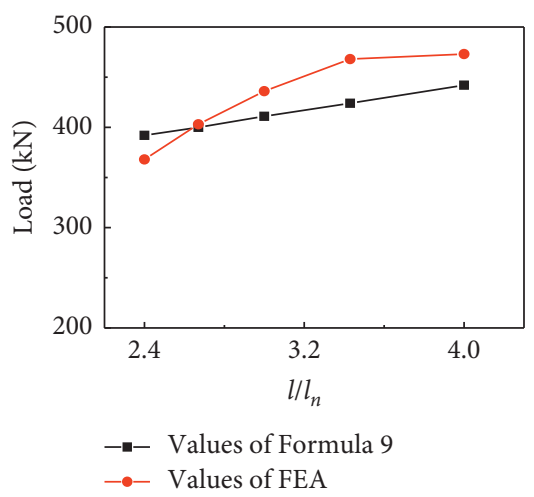

FIgURE 35: Values of formula (9) and FEA under changing of vertical height of shear key (models FE24 to FE28).

shear key is 0 . When the LR ratio of shear key is $0.6 \%-7 \%$, the relative error between them is $0 \%-7 \%$, indicating that the increase of LR ratio of shear key has little effect on shear capacity, and the results are consistent with the test. According to Figure 35 , when $l_{n} / h$ is less than or equal to 1 , and $l / l_{n}$ is equal to 2.4 to 4 , the relative error between the values of FEA and formula (9) is $1 \%-10 \%$, showing that $l / l_{n}$ in the formula is reasonable. The results of parametric analysis further show that formula (9) proposed is reliable and necessary.

\section{Conclusion}

(1) The failure of shear key is controlled by the degree of crack development in shear key-chords connection area, the shear key is horizontally cut, and the concrete of connection area is crushed or pull apart. The failure mode and ultimate shear bearing capacity have almost no relationship with the LR ratio of shear key.

(2) The load stress-strain curves of longitudinal bars and load-displacement curves of shear key have obvious yield characteristics and underwent elastic, elastoplastic. and plastic stages. The stirrup of shear key can be arranged according to the constructional reinforcement.

(3) The stress pattern of shear keys is similar to the reinforced concrete corbel, and formula (6) can accurately estimate the corresponding load value when the shear key-chord connection area cracks.

(4) According to the failure pattern and the restricted condition of reinforced concrete deep flexural member in Chinese code, formula (9) to calculate the shear bearing capacity of shear key is put forward. In engineering application, the shear bearing capacity of shear key can be calculated by formula (7), but the value cannot be larger than the value calculated by formula (9); namely, the shear bearing capacity should meet the restricted condition of shear section.

(5) The FEA results of the test specimens are consistent with those of test results, and the parametric analysis further verifies the reason of the restricted condition of shear section proposed in this paper.

\section{Data Availability}

The bearing capacity data used to support the findings of this study are included within the article.

\section{Conflicts of Interest}

The authors declare that there are no conflicts of interest regarding the publication of this paper. 


\section{Acknowledgments}

This work was sponsored by the National Natural Science Foundation of China (Grant no. 51168008). The supports are gratefully acknowledged.

\section{References}

[1] K. J. Ma, H. G. Zhang, and T. Zheng, Theory and Practice of New Type Architectural Space Gridding Structures, People's Communications Publishing House, Beijing, China, 2006.

[2] H. G. Zhang, L. Hu, K. J. Ma, and T. Zheng, "Analysis of static performance of Vierendeel sandwich plate and its practical calculation method," Journal of Guizhou University of Technology (Natural Science Edition), vol. 35, pp. 82-87, 2006.

[3] H. G. Zhang and K. J. Ma, "A simplified algorithm for the stiffness analysis of sandwich plate and its static performance analysis," Journal of Guizhou University of Technology (Natural Science Edition), vol. 32, pp. 66-71, 2003.

[4] H. Luan, K. Ma, Y. Qin, Z. Chen, and Y. Wei, "Investigation of the structural behavior of an innovative steel open-web floor system," International journal of steel structures, vol. 17, no. 4, pp. 1365-1378, 2017.

[5] Z. P. Chen, G. Wu, D. C. Feng, and K. J. Ma, "Numerical study of the static and dynamic characteristics of reinforced concrete cassette structures for high-rise buildings," The Structural Design of Tall and Special Buildings, vol. 28, no. 18, 2018.

[6] L. Jiang, K. Ma, H. Zhang, Q. Wu, H. Lu, and Q. Yang, "Seismic behavior of shear connectors of steel vierendeel sandwich plate," Mathematical Problems in Engineering, vol. 2019, Article ID 8047393, 14 pages, 2019.

[7] W. Zhao, S. Lu, and X. Jing, "Shear performance of highstrength bolt connector considering different pad and bolt hole," Structure, vol. 28, pp. 1291-1300, 2020.

[8] B. Shan, Y. Xiao, W. L. Zhang, and B. Liu, "Mechanical behavior of connections for glubam-concrete composite beams," Construction and Building Materials, vol. 143, pp. 158-168, 2017.

[9] Z. Q. Bai, K. J. Ma, T. Sun, and Y. Q. Lu, "Study on the basic frequency of reinforced concrete Vierendeel sandwich plate," Industrial Construction, vol. 46, pp. 108-113, 2016.

[10] H. Shang, K. Ma, Y. Wei, and Y. Lu, "Experimental studies on shear resistance performances for the shear key of $\mathrm{H}$ shape steel spatial grid roofs," Latin American Journal of Solids and Structures, vol. 16, p. 17, 2019.

[11] R. Shen, J. Xiao, K. Ma, J. Mao, G. Li, and W. Zeng, “Theoretical and experimental study on steel open-web sandwich floor with flanged cruciform section shear key," Latin American Journal of Solids and Structures, vol. 17, p. 20, 2020.

[12] H. Al-kroom, M. Thneibat, Y. Alghrir, and V. Schmid, "An experimental investigation of new bent V-shaped shear connector," Latin American Journal of Solids and Structures, vol. 18, p. e378-e, 2021.

[13] S. Wang, J. He, Y. Liu, C. Li, and H. Xin, "Shear capacity of a novel joint between corrugated steel web and concrete lower slab," Construction and Building Materials, vol. 163, pp. 360-375, 2018.

[14] M. Mensinger, S. Pfenning, S. Brunkhorst, and J. Zehfu, "Investigation of the effects on the shear connection of composite beams under various fire exposure," in Proceedings of the 2017 - 2nd International Fire Safety Symposium, IFireSS, Tokyo, Japan, June 2017.

[15] Y. Zhang, B. Chen, A. Liu et al., "Experimental study on shear behavior of high strength bolt connection in prefabricated steel-concrete composite beam," Composites Part B: Engineering, vol. 159, pp. 481-489, 2019.

[16] R. M. Lawson and H. Taufiq, "Partial shear connection in light steel composite beams," Journal of Constructional Steel Research, vol. 154, pp. 55-66, 2019.

[17] C.-L. Wang, J. Lyu, J. Zhao, and H. Yang, "Experimental investigation of the shear characteristics of steel-to-timber composite joints with inclined self-tapping screws," Engineering Structures, vol. 215, Article ID 110683, 2020.

[18] Y. Jiang, W. Hong, X. Hu, R. Crocetti, L. Wang, and W. Sun, "Early-age performance of lag screw shear connections for glulam-lightweight concrete composite beams," Construction and Building Materials, vol. 151, pp. 36-42, 2017.

[19] J. Fan, C. Liu, Y. Yang, Y. Bai, and C. Wu, "Shear capacity of 3D composite CFT joints subjected to symmetric loading condition," Journal of Constructional Steel Research, vol. 112, pp. 242-251, 2015.

[20] B. Rong, H. Li, X. Ma, R. Zhang, and Y. Sun, "Study on shear failure of joint with external stiffener under seismic loads," Structure, vol. 27, pp. 259-273, 2020.

[21] E. S.-s. Lam, Z. Xue, S. Fang, and S. Masqood, "Interior beam column joints with nominal joint shear reinforcement versus unsymmetrical chamfers," Engineering Structures, vol. 220, Article ID 110907, 2020.

[22] Y. Z. Murad, R. Hunifat, and W. Al-Bodour, "Interior reinforced concrete beam-to-column joints subjected to cyclic loading: shear strength prediction using gene expression programming," Case Studies in Construction Materials, vol. 13, Article ID e00432, 2020.

[23] M. Pauletta, D. Di Luca, and G. Russo, "Exterior beam column joints - shear strength model and design formula," Engineering Structures, vol. 94, pp. 70-81, 2015.

[24] S. Mangalathu and J.-S. Jeon, "Classification of failure mode and prediction of shear strength for reinforced concrete beam-column joints using machine learning techniques," Engineering Structures, vol. 160, pp. 85-94, 2018.

[25] C. B. I. Press, Standard Test Methods for concrete Structures, China Architecture \& Buliding Press, Beijing, China, 2012.

[26] B.-T. Huang, Q.-H. Li, S.-L. Xu, and L. Zhang, "Static and fatigue performance of reinforced concrete beam strengthened with strain-hardening fiber-reinforced cementitious composite," Engineering Structures, vol. 199, Article ID 109576, 2019

[27] S. Al-Obaidi, Y. M. Saeed, and F. N. Rad, "Flexural strengthening of reinforced concrete beams with NSM-CFRP bars using mechanical interlocking," Journal of Building Engineering, vol. 31, Article ID 101422, 2020.

[28] Y. B. Abu Tahnat, M. A. Samaaneh, M. M. S. Dwaikat, and A. M. Halahla, "Simple equations for predicting the rotational ductility of fiber-reinforced-polymer strengthened reinforced concrete joints," Structure, vol. 24, pp. 73-86, 2020.

[29] 50010-2010 G, Code for Design of Concrete Structures, China Architecture \& Buliding Press, Beijing, China, 2015.

[30] 22/48-2005 D, Technical Specification for Reinforced Concrete Open-Web Sandwich Plate Structures, Guizhou Provincial Department of Housing and Urban-Rural Development, Guiyang, China, 2005.

[31] Gb/T50152-2012, Standard Test Methods for Concrete Structures, China Architecture \& Buliding Press, Beijing, China, 2012.

[32] R. A. Hawileh, M. Z. Naser, and J. A. Abdalla, "Finite element simulation of reinforced concrete beams externally strengthened with short-length CFRP plates," Composites Part B: Engineering, vol. 45, no. 1, pp. 1722-1730, 2013. 
[33] G. Sakar, R. A. Hawileh, M. Z. Naser, J. A. Abdalla, and M. Tanarslan, "Nonlinear behavior of shear deficient RC beams strengthened with near surface mounted glass fiber reinforcement under cyclic loading," Materials \& Design, vol. 61, pp. 16-25, 2014.

[34] K. W. William, "Constitutive model for the triaxial behavior of concrete," Proceedings of the International Association for Business and Society, vol. 19, 1975.

[35] R. A. Hawileh, T. A. El-Maaddawy, and M. Z. Naser, "Nonlinear finite element modeling of concrete deep beams with openings strengthened with externally-bonded composites," Materials \& Design, vol. 42, pp. 378-387, 2012.

[36] L. F. Hussein, M. M. Khattab, and M. S. Farman, "Experimental and finite element studies on the behavior of hybrid reinforced concrete beams," Case Studies in Construction Materials, vol. 15, Article ID e00607, 2021. 